\title{
Impact of Partial Root Drying and Soil Mulching on Squash Yield and Water Use Efficiency in Arid
}

\author{
Abdulhalim H. Farah ${ }^{1}$, Hussein M. Al-Ghobari ${ }^{1}$, Tarek K. Zin El-Abedin ${ }^{2}$, Mohammed S. Alrasasimah ${ }^{1}$ \\ and Ahmed A. El-Shafei 1,2,*(D) \\ 1 Agricultural Engineering Department, College of Food and Agricultural Sciences, King Saud University, \\ Riyadh 11451, Saudi Arabia; enghersi61@gmail.com (A.H.F.); hghobari@ksu.edu.sa (H.M.A.-G.); \\ m.alrsasmah1@gmail.com (M.S.A.) \\ 2 Agricultural Engineering Department, Faculty of Agriculture, Alexandria University, \\ Alexandria 21545, Egypt; drtkz60@gmail.com \\ * Correspondence: aelshafei1bn.c@ksu.edu.sa; Tel.: +966-11-4678504
}

Citation: Farah, A.H.; Al-Ghobari, H.M.; Zin El-Abedin, T.K.;

Alrasasimah, M.S.; El-Shafei, A.A. Impact of Partial Root Drying and Soil Mulching on Squash Yield and Water Use Efficiency in Arid. Agronomy 2021, 11, 706. https:// doi.org/10.3390/agronomy11040706

Academic Editor: Aliasghar Montazar

Received: 25 February 2021

Accepted: 4 April 2021

Published: 7 April 202

Publisher's Note: MDPI stays neutral with regard to jurisdictional claims in published maps and institutional affiliations.

Copyright: (c) 2021 by the authors. Licensee MDPI, Basel, Switzerland. This article is an open access article distributed under the terms and conditions of the Creative Commons Attribution (CC BY) license (https:// creativecommons.org/licenses/by/ $4.0 /)$.

\begin{abstract}
Practical and sustainable water management systems are needed in arid regions due to water shortages and climate change. Therefore, an experiment was initiated in winter (WS) and spring (SS), to investigate integrating deficit irrigation, associated with partial root drying (PRD) and soil mulching, under subsurface drip irrigation on squash yield, fruit quality, and irrigation water use efficiency (IWUE). Two mulching treatments, transparent plastic mulch (WM) and black plastic mulch (BM), were tested, and a treatment without mulch (NM) was used as a control. Three levels of irrigation were examined in a split-plot design with three replications: 100\% of crop evapotranspiration (ETc), representing full irrigation (FI), 70\% of ETC (PRD70), and 50\% of ETc (PRD50). There was a higher squash yield and lower IWUE in SS than WS. The highest squash yields were recorded for PDR70 (82.53 $\mathrm{Mg} \mathrm{ha}^{-1}$ ) and FI (80.62 $\left.\mathrm{Mg} \mathrm{ha}^{-1}\right)$. The highest IWUE was obtained under PRD50. Plastic mulch significantly increased the squash yield (34\%) and IWUE (46\%) and enhanced stomatal conductance, photosynthesis, transpiration, leaf chlorophyll fluorescence, and leaf chlorophyll contents under PRD plants. These results indicate that in arid and semi-arid regions, soil mulch with deficit PRD could be used as a water-saving strategy without reducing yields.
\end{abstract}

Keywords: squash; partial root drying; water use efficiency; soil mulch; growing seasons; gas exchange; fruit quality

\section{Introduction}

Increasing the consumption of water in the agricultural sector, and a lack of preventative measures to permanently conserve water and avoid water shortages, make it vital to manage water resources rather than develop new ways to supply water. Therefore, the need to develop practical and sustainable management systems for water supply has become a subject of intense discussion. Drip irrigation is a promising irrigation strategy that reduces soil evaporation and deep drainage losses, while efficiently delivering water to plant roots [1]. Compared with conventional methods, drip irrigation has shown its utility for water-saving and the efficient use of fertilizers, especially fruit and vegetable crops [2].

Various methods are currently used to increase the efficiency of delivering water to plants. One of these is subsurface drip irrigation (SSDI), which is primarily utilized to decrease water loss during water delivery to plants. Compared with other drip irrigation methods, SSDI has gained more acceptance in the irrigation sector in its ability to increase crop yield and reduce plant diseases and soil erosion [3-5]. Other methods that are used to efficiently managing water irrigation include deficit irrigation (DI) and soil mulching. Ever since the focus of water irrigation shifted from increasing yield per planted area to increasing yield per unit volume of water applied [6], DI has become an important strategy in arid and semi-arid regions where water shortages are a major limitation to farming. 
Therefore, the optimal goal of using DI is to save water, either by reducing the number of irrigation cycles or reducing the volume of water applied during each irrigation event [7]. Irrigation water use efficiency (IWUE) has been developed to indicate increasing crop yield while using less water, or maximizing yield in limited water sources [8]. IWUE was defined by the total yield to the total water applied $[9,10]$. In a physiological perspective, IWUE is used to describe the amount of carbon to the water lost through transpiration [11]. However, agronomists primarily focus on maximizing yield per water applied [12].

Partial root drying (PRD) is an improved form of DI strategy that involves applying water to the sides of a plant root zone, either by irrigating one side of the plant root (fixed PRD) or alternately watering both sides of the root (alternating PRD) [13]. Adequate water and nutrients are delivered to the plant on the wet side of the root, while the dry side is stimulated and releases chemical hormones. These chemical hormones cause stomata to partially close, which increases IWUE [13]. This strategy makes PRD more efficient than DI [13-15]. Barideh et al. [16] reported that alternating PRD saves more water than fixed PRD. Several studies have shown the advantages of DI and PRD over full irrigation (FI), in terms of IWUE without the reduction of yield [17-20]. A number of researchers working on different crops found that the PRD strategy increased IWUE by 38-53\% compared with FI without a significant reduction in yield [18,21,22]. Ors et al. [23] reported that deficit irrigation $(67 \%)$ had significantly reduced chlorophyll index value $(7 \%)$, leaf water content $(42 \%)$, stomatal conductance $(69 \%)$, transpiration $(62 \%)$, photosynthesis $(62 \%)$ of squash. Al-Ghobari and Dewidar [24] indicated that deficit irrigation significant affected the fresh leaf, stem weight of tomato, compared with full irrigation. In terms of fruit quality, PRD preserved fruit quality, compared with deficit irrigation. Zhang et al. [25] reported that PRD was not affected by soluble solid contents of strawberry, while deficit irrigation considerably decreased soluble solid contents. Guang-Cheng et al. [26] indicated that both PRD50 and DI50 strategies considerably decreased dry weigh of shoot and root pepper compared with full irrigation. Furthermore, PRD50 reduced photosynthesis $19 \%$ while DI50 decreased $22 \%$. In chlorophyll fluorescence (FV /Fm) PRD50 reduced by $9.5 \%$ while DI50 decreased $12.0 \%$.

Another method that can increase IWUE is soil mulching, which can be used for many purposes in the agriculture sector. However, preserving soil moisture, improving soil physical properties, and controlling soil erosion are the most significant uses of soil mulching in arid and semi-arid regions $[27,28]$. Mulching materials positively affect the moisture of the soil by improving soil structure and soil retention, as well as decreasing soil evaporation [27,29-31]. Yaghi et al. [32] reported that combining drip irrigation with plastic mulch increased cucumber yield ( $45 \%)$ and IWUE $(72 \%)$ compared with the treatment without mulch during two successive growing seasons in the arid region. Abhivyakti et al. [33] found that black plastic mulch increased the tomato yield by 30\% compared with bare soil in open field conditions. Abd El-Mageed et al. [34] also reported that soil mulching increased both, the squash yield and IWUE by $26 \%$, compared with the non-mulched treatments. Experimenting on broccoli, Verma et al. [35] observed that mulching increased the photosynthetic rate, stomatal conductance, intercellular $\mathrm{CO}_{2}$ concentration, and transpiration rate. Additionally, Lira-Saldivar et al. [36] found that plastic mulch significantly increased photosynthetic activity in zucchini plants $(17.9 \%)$ compared with non-mulched treatments.

In addition to water, growing season also influences both crop yield and IWUE. Numerous studies on zucchini squash have reported that growing season has a significant effect on crop yield and IWUE $[9,34,37,38]$.

Despite numerous studies that have been conducted on SSDI, PRD irrigation and soil mulching, as water management strategies, combined with arid regions with different growing seasons, has not been fully investigated. Therefore, this study aimed to investigate the effect of DI levels, associated with PRD strategy and plastic mulch on squash yield and IWUE in winter and spring. This study also examined the combined effects of PRD, soil mulch, and growing season on gas exchanges, chlorophyll fluorescence, and the chlorophyll content index at different plant growth stages. 


\section{Materials and Methods}

\subsection{Experimental Design and Growth Conditions}

Two experiments were conducted in two consecutive growing seasons: the winter season (WS) and spring season (SS) of 2018-2019 at the Educational farm, King Saud University, Riyadh, which is in an arid area. A meteorological station was set up to constantly measure weather parameters, namely, air temperature, relative humidity, solar radiation, evapotranspiration, and rainfall throughout the WS and SS (Figures 1 and 2). Field preparations were made, including plowing, grading, and leveling. Then, the irrigation layout was implemented according to the experimental design, as shown in Figure 3.

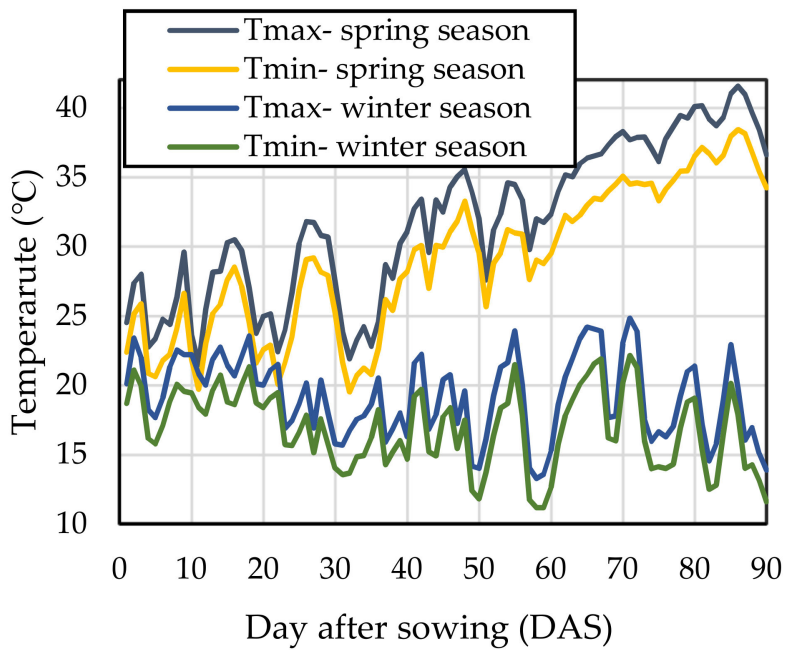

(a)

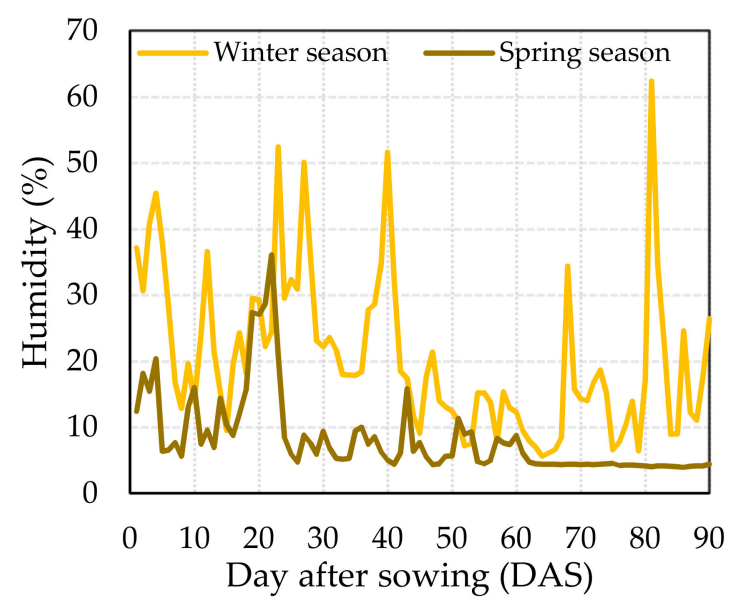

(c)

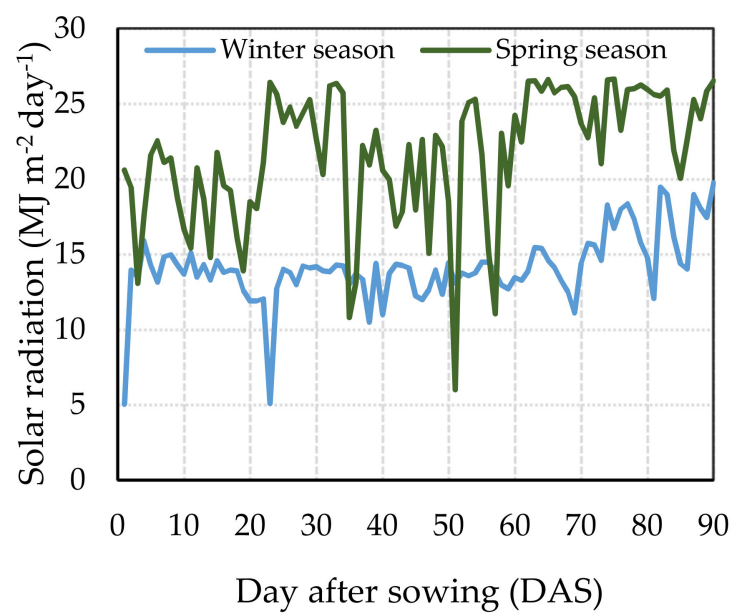

(b)

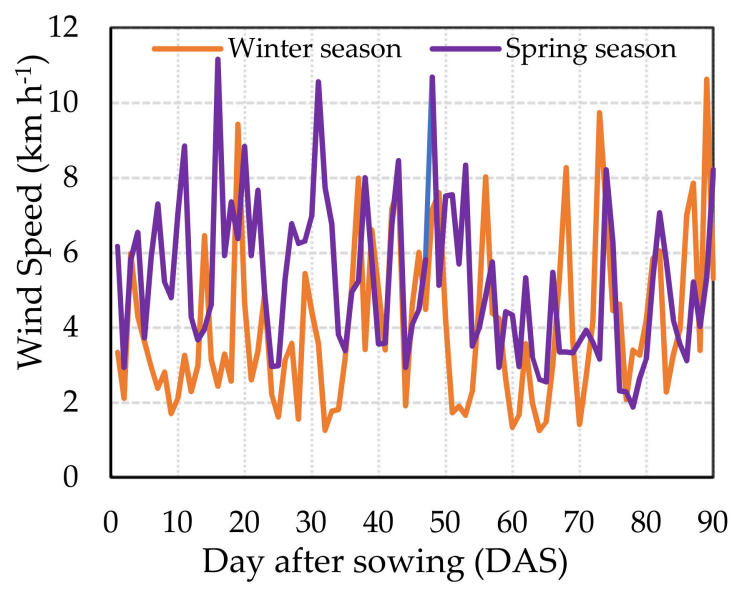

(d)

Figure 1. Daily climate parameters in the winter and spring of 2018-2019 during the squash growing seasons: (a) Daily maximum and minimum temperature, (b) solar radiation, (c) relative humidity, and (d) wind speed. 


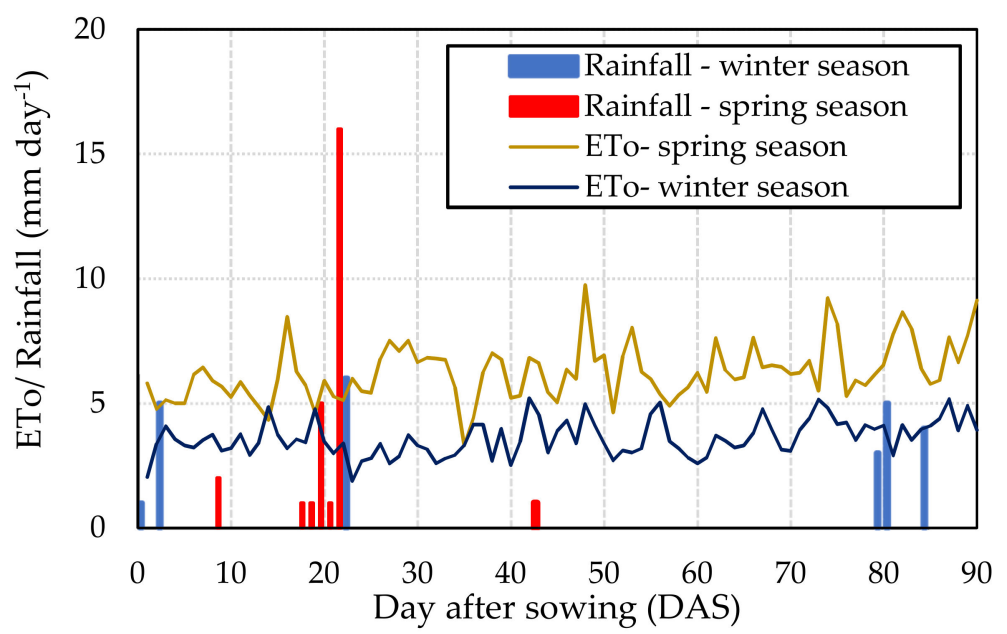

Figure 2. Seasonal reference evapotranspiration (ETo) at the experimental field throughout the winter and spring growing seasons.

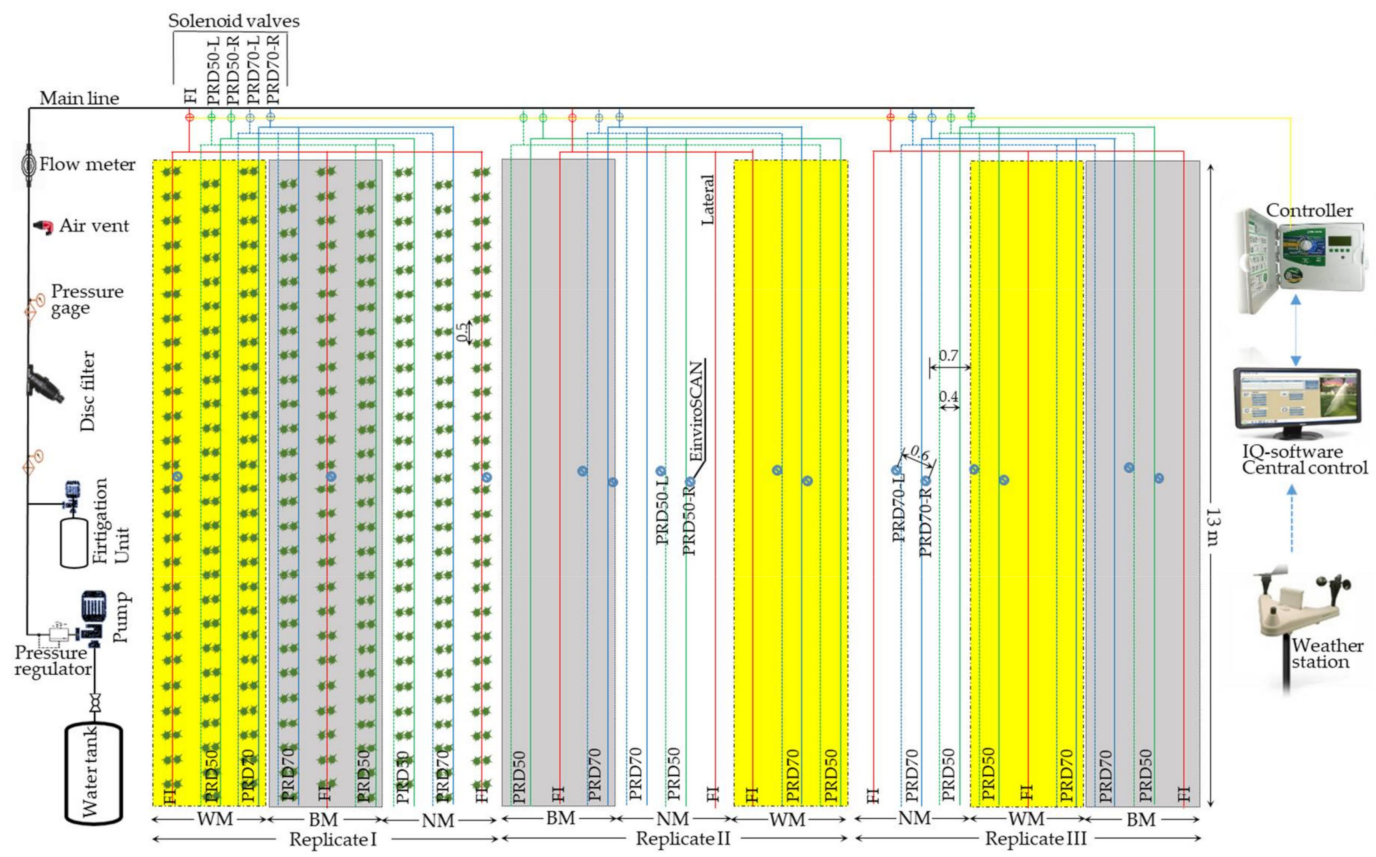

Figure 3. Schematic diagram of the experimental fields under mulch treatments (black mulch-BM, transparent mulch-WM and non-mulch- NM) and irrigation treatments (full irrigation-FI, partial root drying with 50\% of evapotranspirationPRD50, partial root drying with 70\% of evapotranspiration-PRD70).

Soil physical and chemical analyses were conducted by taking soil samples every $0.1 \mathrm{~m}$ down to a depth of $0.5 \mathrm{~m}$, as shown in Table 1. Soil physical parameters were determined, including the field capacity (FC), wilting point (WP), saturated hydraulic conductivity (ks), bulk density $\left(\rho_{b}\right)$, and soil saturation $(S)$. The experiment was conducted in a split-plot design (Figure 3). Treatments were allocated three levels of irrigation and three mulching treatments. The mulching treatments, transparent mulch (WM), black mulch (BM), and without mulch (NM), were assigned as main plots, and the irrigation treatments, FI with $100 \%$ of crop evapotranspiration $\left(\mathrm{ET}_{\mathrm{c}}\right)$, irrigation with $70 \%$ of $\mathrm{ET}_{\mathrm{c}}(\mathrm{PRD} 70)$, and irrigation with $50 \%$ of $\mathrm{ET}_{\mathrm{C}}$ (PRD50\%) were allocated in subplots. The experimental plot area was $13 \mathrm{~m}$ in length by $0.70 \mathrm{~m}$ in row width $\left(9.1 \mathrm{~m}^{2}\right)$. A total of 27 plots were made by replicating each treatment three times. 
Table 1. Soil physical and chemical properties.

\begin{tabular}{|c|c|c|c|c|c|c|c|c|c|c|c|}
\hline \multirow{2}{*}{$\begin{array}{c}\text { Depth } \\
(\mathrm{cm})\end{array}$} & \multicolumn{3}{|c|}{ Particle Size (\%) } & \multirow{2}{*}{ Texture } & \multirow{2}{*}{\multicolumn{2}{|c|}{$\begin{array}{c}\text { FC } \\
\%\end{array}$}} & \multirow{2}{*}{$\begin{array}{c}\mathrm{WP} \\
\%\end{array}$} & \multirow{2}{*}{$\begin{array}{c}\mathbf{k}_{\mathrm{s}} \\
(\mathrm{mm} / \mathrm{h})\end{array}$} & \multirow{2}{*}{$\begin{array}{l}\mathrm{S} \\
\%\end{array}$} & \multirow{2}{*}{\multicolumn{2}{|c|}{$\begin{array}{c}\rho_{\mathrm{b}} \\
\left(\mathrm{g} \mathrm{cm}^{-3}\right)\end{array}$}} \\
\hline & Sand & Silt & Clay & & & & & & & & \\
\hline $0-10$ & 82.90 & 8.80 & 8.30 & $\begin{array}{l}\text { sandy } \\
\text { loam }\end{array}$ & \multicolumn{2}{|c|}{22.11} & 5.53 & 48.06 & 38.15 & \multicolumn{2}{|c|}{1.40} \\
\hline $10-30$ & 74.35 & 16.85 & 8.80 & $\begin{array}{l}\text { sandy } \\
\text { loam }\end{array}$ & \multicolumn{2}{|c|}{21.30} & 4.72 & 18.10 & 35.00 & \multicolumn{2}{|c|}{1.51} \\
\hline $30-50$ & 70.32 & 20.88 & 8.80 & $\begin{array}{l}\text { sandy } \\
\text { loam }\end{array}$ & \multicolumn{2}{|c|}{22.44} & 4.46 & 11.39 & 33.17 & \multicolumn{2}{|c|}{1.57} \\
\hline \multirow{2}{*}{\multicolumn{2}{|c|}{$\begin{array}{l}\text { Depth } \\
\text { (cm) }\end{array}$}} & \multirow{2}{*}{$\mathrm{pH}$} & \multicolumn{4}{|c|}{ Cation $\left(\right.$ meq L $\left.^{-1}\right)$} & \multicolumn{5}{|c|}{ Anions (meq $\mathrm{L}^{-1}$ ) } \\
\hline & & & $\mathrm{Ca}^{2+}$ & $\mathrm{Mg}^{2+}$ & $\mathrm{Na}^{+}$ & $\mathrm{K}^{+}$ & \multicolumn{2}{|c|}{$\mathrm{HCO}_{3}{ }^{-}$} & $\mathrm{CO}_{3}{ }^{2-}$ & $\mathrm{CI}^{-}$ & $\mathrm{SO}_{4}{ }^{2-}$ \\
\hline \multirow{3}{*}{\multicolumn{2}{|c|}{$\begin{array}{c}0-10 \\
10-30 \\
30-50\end{array}$}} & 7.56 & 2.95 & 0.95 & 1.98 & 0.39 & \multicolumn{2}{|c|}{1.25} & 0.00 & 2.45 & 2.35 \\
\hline & & 7.47 & 3.73 & 0.59 & 3.85 & 0.44 & \multicolumn{2}{|c|}{1.28} & 0.00 & 3.10 & 3.45 \\
\hline & & 7.35 & 4.40 & 0.98 & 4.78 & 0.73 & \multicolumn{2}{|c|}{1.78} & 0.00 & 4.00 & 4.48 \\
\hline
\end{tabular}

FC: field capacity; WP: wilting point; $\mathrm{k}_{\mathrm{s}}$ : saturated hydraulic conductivity; $\mathrm{S}$ : soil saturation; $\rho_{\mathrm{b}}$ : bulk density.

\subsection{Applied Irrigation Water}

Drip pipes were buried $15 \mathrm{~cm}$ below the soil surface and had 26 inline emitters, which were spaced at intervals of $0.5 \mathrm{~m}$, and had a discharge rate of $8 \mathrm{~L} \mathrm{~h}^{-1}$ at an operating pressure of $100 \mathrm{kPa}$. In the FI experimental plot, one lateral was installed adjacent to the crop rows, while in the PRD treatments, two laterals with two control valves were installed $0.4 \mathrm{~m}$ apart in each crop row. Irrigation in the PRD treatment was shifted between the two sides of plants every five days.

A weather station (WS-PRO LT Weather Station, Rain Bird) was launched in the experiment field. Daily reference evapotranspiration $\left(E T_{o}\right)$ was calculated from daily climate data according to Allen et al. [39] using Equation (1),

$$
E T_{O}=\frac{0.408 \Delta\left(R_{n}-G\right)+\gamma \frac{900}{T+273} u_{2}\left(e_{S}-e_{a}\right)}{\Delta+\gamma\left(1+0.34 u_{2}\right)}
$$

where $E T_{o}$ is reference crop evapotranspiration $\left(\mathrm{mm} \mathrm{day}^{-1}\right), R_{n}$ is net radiation at the crop surface $\left(\mathrm{MJ} \mathrm{m}^{-2}\right.$ day $\left.^{-1}\right), G$ is soil heat flux density $\left(\mathrm{MJ} \mathrm{m}^{-2} \mathrm{day}^{-1}\right), T$ is mean daily temperature at $2 \mathrm{~m}$ height $\left({ }^{\circ} \mathrm{C}\right), u_{2}$ is wind speed at $2 \mathrm{~m}$ height $\left(\mathrm{m} \mathrm{s}^{-1}\right), e_{S}$ is saturation vapor pressure $(\mathrm{kPa}), e_{a}$ is actual vapor pressure $(\mathrm{kPa}), \Delta$ is the slope of the vapor pressure curve $\left(\mathrm{kPa}{ }^{\circ} \mathrm{C}^{-1}\right)$, and $\gamma$ is a psychrometric constant $\left(\mathrm{kPa}{ }^{\circ} \mathrm{C}^{-1}\right)$.

Irrigation was conducted every day using an automatic controller (ESP-LXME controllers, Rain Bird Corporation, Tucson, AZ, USA), which was connected with a central control (IQ v2.0, Rain Bird Corporation, Azusa, CA, USA). The IQ-software monitored and adjusted watering schedules for the controller and site from a compatible Windows PC, which was connected with the weather station to schedule irrigation automatically based on $E T_{c}$. The crop water requirements $\left(E T_{c}\right)$ were estimated using Equation (2),

$$
E T_{\mathcal{C}}=E T_{o} \times K_{c}
$$

where $E T_{\mathcal{C}}$ is the crop water requirement (crop evapotranspiration; mm day ${ }^{-1}$ ), and $K_{c}$ is the crop coefficient. The crop growth stages, initial, development, mid, and late stage, were $20,30,25$, and 15 days, respectively, and $K_{c}$ of $0.6,1.0$, and 0.75 were used for the initial, mid, and late stage, respectively [39]. Moreover, the values of $K_{c}$ were adjusted according to Allen et al. [39] based on the relative humidity, wind speed at $2 \mathrm{~m}$, percentage of wetted soil surface in the experimental field using Equations (3) and (4),

$$
K_{\text {c ini }}=f_{w} K_{c \text { ini }(\text { Table })}
$$


where $K_{c i n i}$ is the adjusted value of initial $K_{c}, f_{w}$ is the fraction of surfaced wetted by irrigation, and $K_{c \text { ini(Table) }}$ is the value of initial $K_{c}$ from Allen et al. [39].

$$
K_{c \text { mid OR end }}=K_{c \text { mid OR end }(\text { Table })}+\left[0.04\left(u_{2}-2\right)-0.004\left(R H_{\min }-45\right)\right]\left(\frac{h}{3}\right)^{0.3}
$$

where $K_{c}$ mid $O R$ end is the adjusted values of mid $K_{c}$ or end $K_{c}, K_{c}$ mid OR end(Table) is the value of of mid $K_{c}$ or end $K_{c}$ from Allen et al. [39], $R H_{\min }$ is the mean value for daily minimum relative humidity during the mid-season growth stage or the end-season stage [\%], and $h$ is mean plant height during the mid-season stage or the end-season stage [m].

At 20 days after sowing (DAS), PRD70 and PRD50 were applied until harvesting.

\subsection{Plant Management}

Two seeds of zucchini squash, Cucurbita pepo L., were hand-sown $10 \mathrm{~cm}$ apart on both sides of the central line of the planting rows, and there was $0.5 \mathrm{~m}$ between plants within a row. Seeds were planted on November 18, 2018 and terminated on 15 February 2019 in the WS, and in the SS, seeds were planted on 23 March 2019 and terminated on 20 June 2019. Chemical fertilization was applied at the recommended rate for squash production in this area: $5.1 \mathrm{~g} \mathrm{~N} /$ plant, $5.1 \mathrm{~g} \mathrm{P}_{2} \mathrm{O}_{5}$ /plant, $16.8 \mathrm{~g} \mathrm{~K} 2 \mathrm{O} /$ plant, $37.5 \mathrm{~g} \mathrm{Ca}\left(\mathrm{NO}_{3}\right)_{2} /$ plant, $28.5 \mathrm{~mL}$ $\mathrm{H}_{3} \mathrm{PO}_{4} /$ plant, $14.52 \mathrm{~mL} \mathrm{HNO}$ / plant, and $1.41 \mathrm{~g}$ humic acid/plant. Pest management and disease control were conducted based on local squash protection procedures.

\subsection{Soil Moisture Measurements}

Capacitance probes (EnviroSCAN ${ }^{\circledR}$, Sentek Sensor Technologies, Stepney, Australia) were used to measure soil moisture. Enviroscan probes were used to continuously monitor volumetric soil water content $\left(\theta_{v}\right)$ down to a depth of $0.5 \mathrm{~m}$ in the root zone of each irrigation treatment. Probes were installed vertically at a distance of $0.10 \mathrm{~m}$ from laterals and had five sensors at $0.10 \mathrm{~m}$ intervals. Soil frequencies $\left(F_{s}\right)$ were converted into scaled frequencies $\left(S_{f}\right)$ according to Equation (5) following Buss [40],

$$
S_{f}=\frac{F_{A}-F_{S}}{F_{A}-F_{W}}
$$

where $F_{A}$ is the sensor reading in the air, $F_{S}$ is the sensor reading in the soil, and $F_{W}$ is the sensor reading in non-saline water. According to Vera et al. [41], $\theta_{v}$ can be calculated using Equation (6),

$$
\theta_{v}=\left(\frac{S_{f}-C}{A}\right)^{\frac{1}{b}}
$$

where $A=0.1957, b=0.404$, and $C=0.02852$. The determination coefficient value provided using standard default calibration was 0.97 . One EnviroScan device per plot was installed in single lateral treatments (FI), while two EnviroScan devices were installed $0.6 \mathrm{~m}$ apart in the diagonal direction in the two lateral treatments: PRD70 and PRD50 (Figure 3).

\subsection{Physiological and Agronomic Measurements}

Chlorophyll index (soil-plant analysis development (SPAD) value) and gas exchange measurements, including stomatal conductance $\left(g_{s}\right)$, photosynthesis $\left(P_{n}\right)$, and transpiration rate $\left(T_{r}\right)$, were measured at three different growth stages: development (35 DAS), mid (63 DAS), and late stage (83 DAS). One leaf (of the same age) was selected per plant from five plants per plot. A total of 15 measurements per treatment were made at every growth stage.

The chlorophyll index (SPAD value) was measured using a SPAD 502 Plus Chlorophyll Meter (Minolta Co. Ltd., Osaka, Japan). Using a chlorophyll meter is a non-destructive method that quickly and precisely approximates the chlorophyll concentration of leaves by measuring the red $(650 \mathrm{~nm})$ and infrared $(940 \mathrm{~nm})$ radiation of leaves [42]. The sample 
readings were made for every plot using the center section of the selected leaf at all measured growth stages.

The gas exchange measurements $g_{s}, P_{n}$, and $T_{r}$ were measured using an LI-6400XT portable photosynthesis system (LiCor Inc., Lincoln, NE, USA). The samples were measured for each treatment from functional leaves on a cloudless day from 08h00 to $10 \mathrm{~h} 00$ local time.

Total fresh squash yields $\left(\mathrm{Mg} \mathrm{ha}^{-1}\right)$ were determined by manually collecting and weighing fruits from each line for all harvested squash fruits. The irrigation water use efficiency (IWUE) was calculated by dividing the total weight of harvested squash fresh fruits $\left(\mathrm{kg} \mathrm{ha}^{-1}\right)$ by the volume of water applied to the crop $\left(\mathrm{m}^{3} \mathrm{ha}^{-1}\right)[9,10]$.

The fruit quality parameters, total soluble solids (TSS, \%), vitamin C (V $V_{C}, \mathrm{mg}_{100 \mathrm{~g}^{-1}}$ fruit fresh weight-FW), and titratable acidity (TA, \% citric acid), were assessed by choosing samples of three mature fruits in the third, fifth, and seventh harvestings per treatment in each growing season. A squash extract was taken by blending and filtering the flesh of each fruit. A digital refractometer (PR-101 model, ATAGO, Tokyo, Japan) was used to determine the TSS using standard methods of analysis [43], while TA was determined using the procedure, described by Caruso et al. [44]. 2,6-dichlorophenol-indophenol-dye was used to measured $V_{c}$ in the extracted juice [45].

\subsection{Statistical Analysis}

Statistical analysis was conducted using analysis of variance procedures using CoStat version 6.451 [46]. The difference between means was compared using a least significant difference test (LSD) at the $5 \%$ level $(p \leq 0.05)$.

\section{Results and Discussion}

\subsection{Evapotranspiration and Applied Irrigation}

There was variation in the weather parameters of the WS and SS (Figure 1). Air temperature, solar radiation intensity, and wind speed were higher in the SS than the WS. However, in the WS, the relative humidity was higher than in the SS. This caused a 73\% increase in the seasonal reference evapotranspiration $\left(\mathrm{ET}_{\mathrm{o}}\right)$ in the $\mathrm{SS}$, compared with the WS (Figure 2). As irrigation scheduling was based on $\mathrm{ET}_{\mathrm{c}}$, more water was consumed in the SS than the WS (Figure 4).

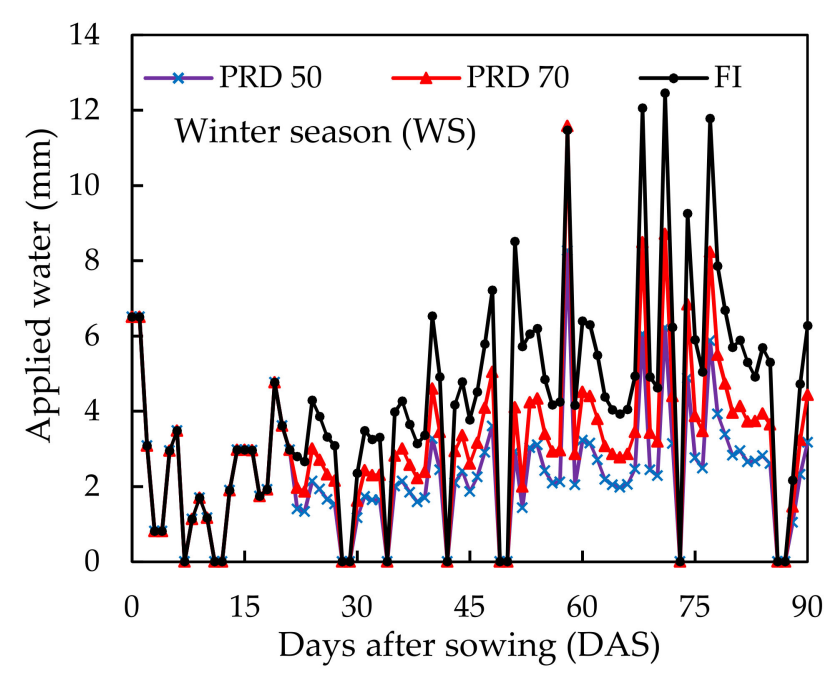

(a)

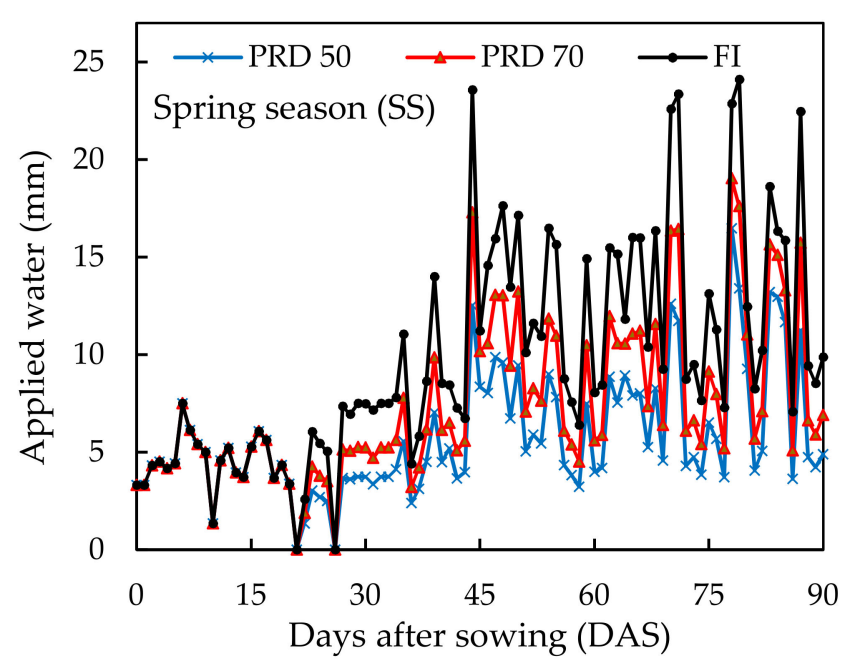

(b)

Figure 4. Seasonal water application to zucchini squash crops for the two growing seasons: (a) Winter season, and (b) spring season. 


\subsection{Soil Moisture Content}

Figure 5 shows the different patterns of soil moisture distribution in their response to FI, PRD70, and PRD50, combined with WM, BM, and NM during the WS and SS. The values presented for volumetric soil moisture content $\left(\theta_{\tau}\right)$ are an average of $0.1,0.2,0.3$, 0.4 , and $0.5 \mathrm{~m}$ soil depths. Before irrigation treatments (20 DAS), the $\theta_{v}$ for all treatments was almost the same for each growing season. Irrigation was scheduled based on ET, and this caused a variation in $\theta_{v}$ between the two seasons. In the WS, the $\theta_{v}$ for FI was below the FC compared with the SS when the $\theta_{v}$ of FI was almost near the FC. The average $\theta_{v}$ in the SS was higher by $16 \%, 22 \%$, and $32 \%$ for $\mathrm{BM}, \mathrm{WM}$, and NM, respectively, than the corresponding values in WS. This was primarily due to the applied water in the SS, which was higher than in the WS (Figure 4). For the mulch treatments, WM and BM showed higher $\theta_{v}$ than NM. The increased moisture retention capacity of the mulched treatments in the two growing seasons could be attributed to less evaporation from the soil, as shown in Figure 5. Besides, vapor accumulation from irrigated water trapped within the mulches cause the formation of fog, which precipitates back into the soil. These findings are in agreement with Yaghi et al. [32] and Rashid et al. [47], who found that mulched treatments showed higher soil moisture content compared to non-mulched treatments. The $\theta_{v}$ values of the PRD treatments showed alternately an increase in the wet side (right) of the root zone, while the dry side (left) showed a reduction in soil moisture content, as shown in Figure 5. The wet side of the root zone delivers water to the plant, while the dry side improves root ventilation. In PRD70, $\theta_{v}$ was between the FC and WP. However, in PRD50, $\theta_{v}$ was below the WP, and this had a negative impact on plant growth. The patterns of soil water dynamics in PRD-treated plants in this study were similar to those described by Barideh et al. [16] and Rashid et al. [47], who found that the soil water content in PRD treatments increased and decreased interchangeably.

\subsection{Stomatal Conductance $\left(g_{s}\right)$, Photosynthesis $\left(P_{n}\right)$, and Transpiration $\left(T_{r}\right)$}

Data in Table 2 show that irrigation quantity significantly $(p<0.001)$ affected the values of $g_{s}$ at all growth stages. At 83 DAS, PRD70 and PRD50 reduced the value of $g_{s}$ by $10 \%$ and $37 \%$ compared with FI, respectively. This is due to plant age, which reduces its activity. FI showed a higher $\mathrm{P}_{\mathrm{n}}$ rate compared with the PRD treatments. At 63 DAS, $P_{n}$ values under the FI plot were $10.685 \mu \mathrm{mol} \mathrm{m}^{-2} \mathrm{~s}^{-1}$. This is a $7 \%$ and $16 \%$ increase compared with PRD70, and PRD50, respectively. $\mathrm{T}_{\mathrm{r}}$ was significantly affected $(p<0.001)$ by irrigation quantity at all measured days. The lowest $T_{r}$ values were observed under PRD50 treatments at 63 DAS.

However, FI treatments showed the highest $\mathrm{T}_{\mathrm{r}}\left(4.046 \mathrm{mmol} \mathrm{m}^{-2} \mathrm{~s}^{-1}\right)$ at $35 \mathrm{DAS}$, which was not statistically different from PRD70. This finding indicates that the water deficit in PRD70 did not affect transpiration efficiency. At 83 DAS, PRD50 and PRD70 reduced the $T_{r}$ values by $20 \%$ and $17.6 \%$, respectively, compared with the FI treatments. In this study, the irrigation treatment significantly affected the $g_{s}, P_{n}$, and $T_{r}$ values, indicating that both $P_{n}$ and $T_{r}$ are controlled by $g_{s}$, and they mutually affect each other $[48,49]$. Liu et al. [50] stated that under water-stressed conditions, $g_{s}$ decreases due to the closure of stomata to maintain leaf water status. However, there are opposing reports on the mechanism behind stomatal closure [51]. Although some studies suggest that chemical signals, such as abscisic acid (ABA) and $\mathrm{pH}$ are behind stomatal closure [50,52], others endorse that hydraulic signals, such as soil, root, and shoot resistances, are responsible for stomatal closure [53]. Many questions still arise related to the mechanism behind stomatal closure, even though many studies have been conducted [51]. Farooq et al. [54] stated that stomatal closure reduces the amount of carbon dioxide going into the parenchyma cells, which causes inhabitation of $\mathrm{CO}_{2}$ and light that ultimately affects plant photosynthesis efficiency. 


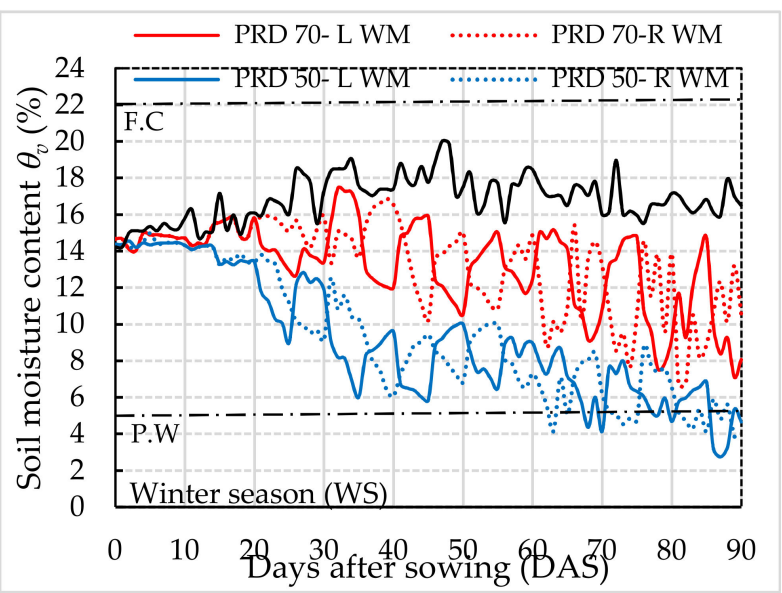

(a)

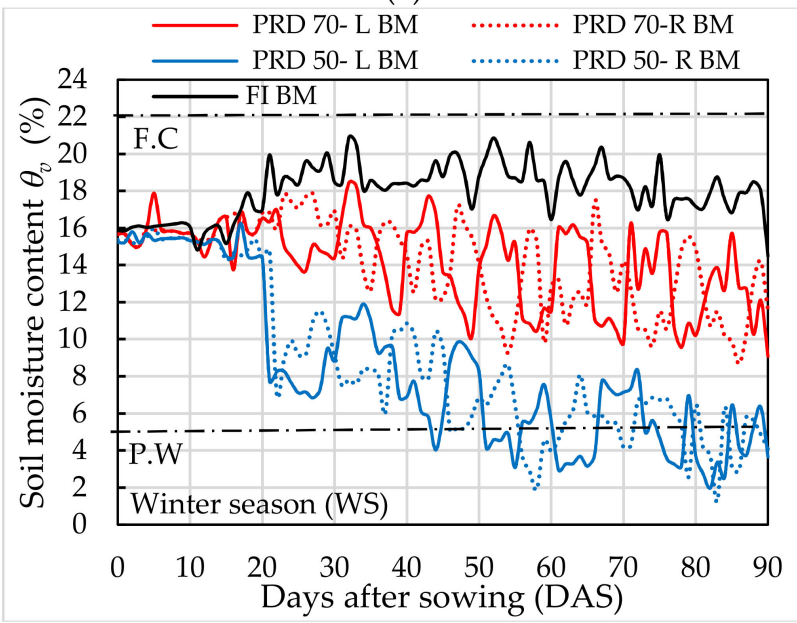

(c)

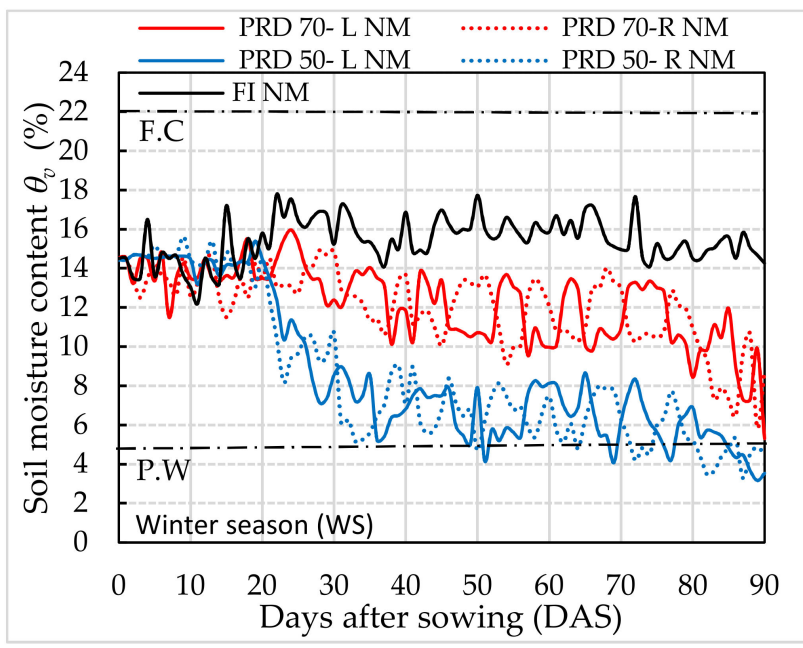

(e)

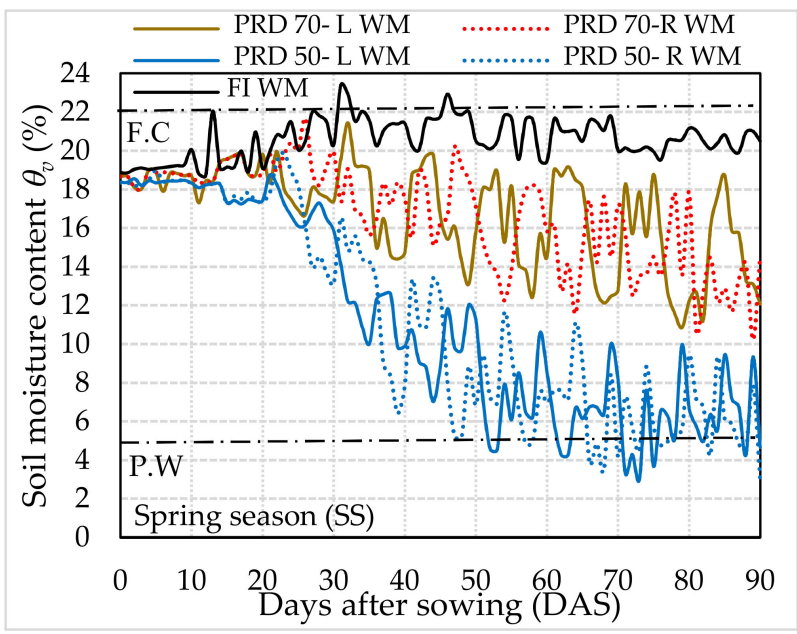

(b)

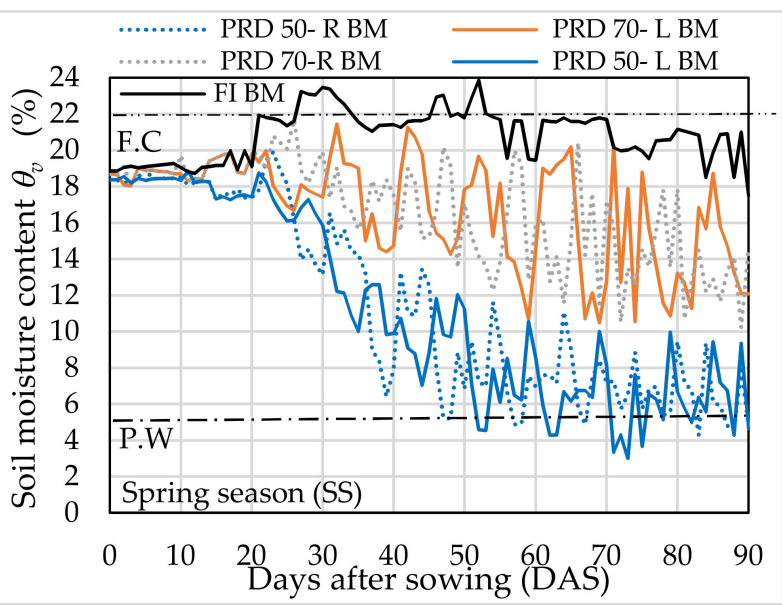

(d)

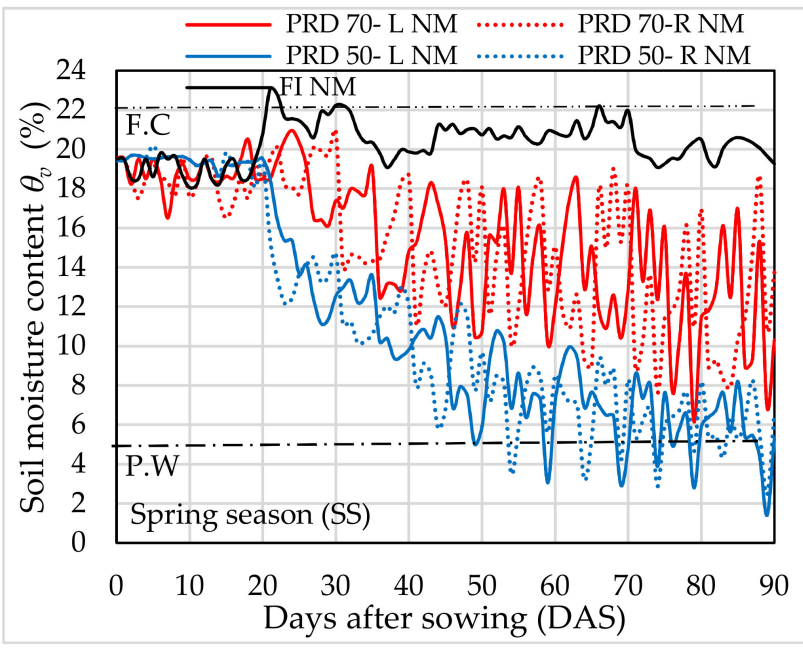

(f)

Figure 5. Soil moisture for full irrigation (FI) and deficit partial rootzone drying under 70\% and 50\% of evapotranspiration (PRD70 and PRD50, respectively) at the left (L) and right (R) rootzone sides combined with: (a) Transparent mulch (WM) during the winter season (WS), (b) WM during the spring season (SS), (c) black mulch (BM) during the WS, (d) BM during the SS, (e) no mulch (NM) during the WS, and (f) NM during SS. FC, field capacity, and WP, wilting point. 
Table 2. Analysis of variance of stomatal conductance $\left(\mathrm{g}_{\mathrm{s}}\right)$, photosynthesis $\left(\mathrm{P}_{\mathrm{n}}\right)$, and transpiration $\left(\mathrm{T}_{\mathrm{r}}\right)$ at the development stage (35 DAS), mid stage (63 DAS), and late stage (83 DAS) of squash growth during the winter (WS) and spring (SS) growing seasons.

\begin{tabular}{|c|c|c|c|c|c|c|c|c|c|c|}
\hline \multirow{2}{*}{ Treatments } & & \multicolumn{3}{|c|}{$\mathrm{g}_{\mathrm{s}}\left(\mathrm{mol} \mathrm{H}_{2} \mathrm{O} \mathrm{m}^{-2} \mathrm{~s}^{-1}\right)$} & \multicolumn{3}{|c|}{$P_{n}\left(\mu \mathrm{mol} \mathrm{CO} \mathrm{Cm}^{-2} \mathrm{~s}^{-1}\right)$} & \multicolumn{3}{|c|}{$\mathrm{T}_{\mathrm{r}}\left(\mathrm{mmol} \mathrm{H}_{2} \mathrm{O} \mathrm{m}^{-2} \mathrm{~s}^{-1}\right)$} \\
\hline & & 35 DAS & 63 DAS & 83 DAS & 35 DAS & 63 DAS & 83 DAS & 35 DAS & 63 DAS & 83 DAS \\
\hline \multirow{4}{*}{ Season (S) } & WS & $0.2912^{b}$ & $0.2192^{b}$ & $0.1722^{b}$ & $8.647^{b}$ & $9.335^{b}$ & $9.1668^{b}$ & $3.115^{b}$ & $2.804^{b}$ & $2.887^{b}$ \\
\hline & SS & $0.3881^{\mathrm{a}}$ & $0.3182^{\mathrm{a}}$ & $0.2122^{\mathrm{a}}$ & $9.657^{\mathrm{a}}$ & $10.414^{\mathrm{a}}$ & $10.381^{\mathrm{a}}$ & $4.285^{\mathrm{a}}$ & $3.952^{\mathrm{a}}$ & $3.836^{\mathrm{a}}$ \\
\hline & $p$-value & $0.0059 * *$ & $0.0006^{* *}$ & 0.0126 * & 0.023 * & $0.0465 *$ & $0.0172 *$ & 0.014 * & $0.0002 * *$ & $0.0039 * *$ \\
\hline & LSD0.05 & 0.032 & 0.0107 & 0.019 & 0.678 & 1.037 & 0.694 & 0.602 & 0.072 & 0.254 \\
\hline \multirow{5}{*}{ Mulch (M) } & WM & 0.3445 & $0.3004^{a}$ & $0.2257^{\mathrm{a}}$ & $10.176^{a}$ & $9.961^{b}$ & $10.256^{a}$ & $4.046^{\mathrm{a}}$ & $3.812^{\mathrm{a}}$ & $3.852^{\mathrm{a}}$ \\
\hline & BM & 0.3401 & $0.2660^{b}$ & $0.1818^{b}$ & $9.778^{a}$ & $10.461^{a}$ & $10.088^{a}$ & $3.901^{\mathrm{a}}$ & $3.359^{b}$ & $3.173^{b}$ \\
\hline & $\mathbf{N M}$ & 0.3262 & $0.2397^{c}$ & $0.1690^{c}$ & $7.502^{b}$ & $9.200^{c}$ & $8.976^{b}$ & $3.150^{b}$ & $2.963^{c}$ & $3.061^{b}$ \\
\hline & $p$-value & $0.0527^{\mathrm{ns}}$ & $0.00001^{* *}$ & $0.0001^{* *}$ & $0.00001^{* *}$ & $0.00001^{* *}$ & $0.0001^{* *}$ & $0.00001^{* *}$ & $0.00001^{* *}$ & $0.0001^{* *}$ \\
\hline & LSD0.05 & - & 0.014 & 0.0095 & 0.451 & 0.151 & 0.273 & 0.169 & 0.093 & 0.132 \\
\hline \multirow{5}{*}{$\begin{array}{l}\text { Irrigation } \\
\text { (I) }\end{array}$} & FI & $0.375^{a}$ & $0.3222^{a}$ & $0.2284^{a}$ & $10.562^{a}$ & $10.685^{a}$ & $10.333^{a}$ & $4.044^{\mathrm{a}}$ & $3.826^{a}$ & $3.603^{a}$ \\
\hline & PRD70 & $0.333^{b}$ & $0.2557^{\mathrm{b}}$ & $0.2051^{\mathrm{a}}$ & $9.0196^{b}$ & $9.972^{b}$ & $9.594^{b}$ & $3.792^{\mathrm{a}}$ & $3.272^{b}$ & $3.414^{b}$ \\
\hline & PRD50 & $0.310^{c}$ & $0.2283^{c}$ & $0.1431^{b}$ & $7.875^{c}$ & $8.965^{c}$ & $9.394^{b}$ & $3.265^{b}$ & $3.036^{c}$ & $3.069^{c}$ \\
\hline & $p$-value & $0.0001 * *$ & $0.00001^{* *}$ & $0.00001^{* *}$ & $0.00001 * *$ & $0.00001 * *$ & $0.0005^{* *}$ & $0.00001 * *$ & $0.00001 * *$ & $0.00001 * *$ \\
\hline & LSD0.05 & 0.0149 & 0.016 & 0.028 & 0.416 & 0.313 & 0.44 & 0.261 & 0.092 & 0.142 \\
\hline $\mathbf{S} \times \mathbf{M}$ & $p$-value & $0.9732^{\mathrm{ns}}$ & $0.68^{\mathrm{ns}}$ & 0.013 * & $0.99^{\mathrm{ns}}$ & $0.971^{\mathrm{ns}}$ & $0.936^{\mathrm{ns}}$ & $0.664^{\mathrm{ns}}$ & $0.404^{\mathrm{ns}}$ & $0.0251 *$ \\
\hline $\mathbf{S} \times \mathbf{I}$ & $p$-value & $0.9948^{\mathrm{ns}}$ & $0.99^{\mathrm{ns}}$ & $0.85^{\mathrm{ns}}$ & $0.99^{\mathrm{ns}}$ & $0.989^{\mathrm{ns}}$ & $0.909^{\mathrm{ns}}$ & $0.924^{\mathrm{ns}}$ & $0.438^{\mathrm{ns}}$ & $0.0066^{* *}$ \\
\hline $\mathbf{M} \times \mathbf{I}$ & $p$-value & $0.4528^{\mathrm{ns}}$ & $0.15^{\mathrm{ns}}$ & $0.23^{\mathrm{ns}}$ & $0.0002^{* *}$ & 0.011 * & $0.171^{\mathrm{ns}}$ & $0.851^{\mathrm{ns}}$ & $0.0005^{* *}$ & $0.00001^{* *}$ \\
\hline $\mathbf{S} \times \mathbf{M} \times \mathbf{I}$ & $p$-value & $0.9980^{\mathrm{ns}}$ & $0.99^{n s}$ & $0.91^{\mathrm{ns}}$ & $1^{\mathrm{ns}}$ & $0.999 \mathrm{~ns}$ & $0.999 \mathrm{~ns}$ & $0.994^{\mathrm{ns}}$ & $0.788^{\mathrm{ns}}$ & $0.00001^{* *}$ \\
\hline
\end{tabular}

WS: winter season; SS: spring season; WM: transparent mulch; BM: black mulch; NM: no mulch FI: full irrigation; PRD70 and PRD50: deficit partial rootzone drying under 70 and 50 of evapotranspiration, respectively; S, M and I: season, mulch and irrigation treatments, respectively; $\mathrm{S} \times \mathrm{M} \times \mathrm{I}$ : interaction between season, mulch and irrigation treatments; ${ }^{\text {ns: }}$ not statistically significant; ${ }^{* *}$ : significant at the $1 \%$ level $(p<0.01)$; ${ }^{*}$ significant at the $5 \%$ level $(p<0.05)$; different letters indicate significant difference between treatments; bold letters and words indicate treatments names.

Our results indicated that $P_{n}$ decreased with a decrease in $g_{s}$ at the same stage of plant growth, but in different growth stages, a decrease in $\mathrm{g}_{\mathrm{s}}$ did not cause a decrease in $\mathrm{P}_{\mathrm{n}}$. For instance, at the mid stage (63 DAS), the $P_{n}$ values increased despite $g_{s}$ reduction in both the mulch and irrigation treatments for the two growing seasons (Table 2). This could be explained by the squash leaves having reached their maximum area at this stage, when plants reach their peak values of most photosynthetic parameters [55]. The leaf $g_{s}, P_{n}$, and $\mathrm{T}_{\mathrm{r}}$ in the PRD treatments were significantly lower than that of FI at all measured days. In the PRD treatment, two sides of the root were alternately irrigated. The side of the root that undergoes a water deficit for a period induces $\mathrm{ABA}$, which reduces $\mathrm{g}_{\mathrm{s}}$, affecting both transpiration and photosynthesis efficiencies. However, the watered side of the root keeps the plant in a preferable situation [13]. In the current study, due to water stress under PRD treatment, plants induced $\mathrm{ABA}$ from the root to the leaves, resulting in the accumulation of ABA in the leaves causing stomatal closure [50,52]. Several studies showed that plants under PRD could enhance leaf $T_{r}$ [56] and improve the $P_{n}$ rate [57] compared to FI. These results are in agreement with other studies $[5,58]$, which indicated that $g_{s}$ decreases with increasing water stress levels.

The $g_{s}, P_{n}$, and $T_{r}$ were significantly affected by mulching treatments. However, at 35 DAS, $g_{s}$ showed no significant difference $(p>0.05)$ between mulch and non-mulched treatments. At 63 DAS, compared with NM, WM and BM increased $g_{s}$ by $20 \%$ and $10 \%$, respectively, indicating that plants under mulched treatments were healthier at the mid growth stage. At 83 DAS, the NM treatment reduced the $P_{n}$ value by $11 \%$ and $12.5 \%$ compared with the BM and WM treatments, respectively (Table 2). At 35 DAS, the non-mulched treatments reduced the $\mathrm{T}_{\mathrm{r}}$ by $19 \%$ and $22 \%$ compared with the BM and WM treatments, respectively. Our results agree with the findings described by Ibarra-Jiménez et al. [59] and Lira-Saldivar et al. [36], who found that plastic mulch significantly increased photosynthetic activity in zucchini plants compared with non-mulched treatments. This finding is due to the advantage of plastic mulch, which can control soil temperature, enhance soil moisture, 
and elevate crop photosynthesis [60]. Yang et al. [61] and Zhang et al. [62] emphasized that soil hydrothermal state is an essential element in photosynthesis. The proper soil moisture and temperature situation under mulched treatments boost the movement of water from the deep soil to the surface soil by capillary and steam action, increasing the intercellular $\mathrm{CO}_{2}$ concentration in the ear-leaf [62]. These activities help increase carbon sources for leaf photosynthesis, thereby decreasing the limitations of stomatal factors [63] and leading to consistently higher $\mathrm{P}_{\mathrm{n}}$ in mulched than non-mulched treatments.

Data in Table 2 indicate that $g_{s}, P_{n}$, and $T_{r}$ were significantly affected by growing season for all measured days. The highest $g_{s}$ was 0.3881 and $0.2912 \mathrm{mmol} \mathrm{m}^{-2} \mathrm{~s}^{-1}$ in the SS, and WS at 35 DAS, respectively. The Tr in SS and WS followed the same trend as $g_{s}$; the highest $\mathrm{T}_{\mathrm{r}}$ was observed at 35 DAS. At 63 DAS, the $\mathrm{P}_{\mathrm{n}}$ value in the SS increased by $10 \%$, compared with in the WS. Urban et al. [64] revealed that high temperatures affect all physiological processes in plants. Furthermore, Jones et al. [65] and Scherrer et al. [66] asserted that environmental factors, such as radiation, air temperature, and wind, affect the size of the stomata aperture. In this study, the physiological trend $\left(g_{s}, P_{n}\right.$, and $\left.T_{r}\right)$ could be explained by the environmental differences between the two growing seasons, where the SS had higher air temperature, radiation, and wind speed than the WS (Figure 1).

The effects of the growing season, mulch treatment, and irrigation quantities on $g_{s}$, $P_{n}$, and $T_{r}$ were significant at all squash stages (Table 2). This finding indicates that sowing squash during a suitable growing season and choosing a suitable combination of irrigation volume and plastic mulch could enhance squash physiological response, which would ultimately increase the yield and IWUE.

The $g_{s}$ was not significantly affected by interactions between growing season, mulch, and irrigation quantities, as shown in Table 2. However, at 83 DAS, the interaction between season and mulch showed a significance difference $(p<0.05)$. No interaction effect on $P_{n}$ was observed, except for interaction between irrigation and mulch, which significantly affected $(p<0.05) \mathrm{P}_{\mathrm{n}}$ values at 35 DAS and 63 DAS. In 35 DAS, comparing with same irrigation strategies FI, BM increased $\mathrm{P}_{\mathrm{n}} 3 \%$ and $20 \%$, respectively compared with WM and NM. In PRD70, $\mathrm{P}_{\mathrm{n}}$ values under $\mathrm{BM}$ and $\mathrm{WM}$ were not different, while $\mathrm{BM}$ and WM enhanced $P_{n}$ values 37\%, and 36\%, respectively, compared with NM. in PRD50, BM increased $P_{n} 21 \%, 39 \%$, compared with WM and NM, respectively. Data in Table 2 indicate that there was no significant interaction between growing season, mulch, and irrigation on $\mathrm{Tr}$, except after 83 DAS. This indicates that squash plants were not able to withstand environmental changes at a late stage of growth, and there was a water deficit due to the age of the plants. Tr values were reduced under PRD strategies compared with FI for both mulched and non-mulched treatments. At 63 DAS, WM increased Tr 6\% and 14\% compared with BM, and NM, respectively under FI strategy. Using PRD70 and PRD50 Tr values under WM was higher $18 \%$ and $38 \%$ compared with $\mathrm{BM}$, and NM, respectively. At 83DAS, under FI, Tr under BM was higher 10\%, and 17\%, respectively, compared with WM and NM. In PRD 70, WM increased Tr 22\%, and 40\%, respectively, compared with BM and NM. in PRD50, Tr was reduced dramatically due to water stress. However, WM increased Tr by $9 \%$ while BM increased by $7 \%$, compared NM.

\subsection{Chlorophyll Index (SPAD Value)}

The chlorophyll index (SPAD value) was statistically analyzed, as shown in Table 3. High chlorophyll content is a desired attribute, as it implies a low degree of photoinhibition of the photosynthetic apparatus [67]. Li et al. [42] suggested that SPAD values could perfectly trace the variations in chlorophyll content of plants. At 35 and 83 DAS, squash plants sown in the SS showed high chlorophyll content (SPAD value) compared with those sown in the WS. This could be due to the higher photosynthesis rate $\left(P_{n}\right)$, observed in squash plants sown in the SS, compared with those sown in the WS (Table 2). Li et al. [68] and Peiguo and Mingqi [69] emphasized that the relative chlorophyll and photosynthetic rate interact positively with each other, as chlorophyll represents the primary chloroplast component of photosynthesis. 
Table 3. Analysis of variance of the chlorophyll index (SPAD value) at the development stage (35 DAS), mid stage (63 DAS), and late stage (83 DAS) of squash growth during winter (WS) and spring (SS) growing seasons.

\begin{tabular}{|c|c|c|c|c|}
\hline \multirow{2}{*}{ Treatments } & & \multicolumn{3}{|c|}{ Chlorophyll Index (SPAD Value) } \\
\hline & & 35 DAS & 63 DAS & 83 DAS \\
\hline \multirow{4}{*}{ Season (S) } & WS & $43.88^{b}$ & $42.99^{b}$ & $41.66^{b}$ \\
\hline & SS & $48.31^{a}$ & $43.88^{a}$ & $45.85^{a}$ \\
\hline & $p$-value & $0.0083^{* *}$ & $0.196^{\mathrm{ns}}$ & $0.010 *$ \\
\hline & LSD 0.05 & 1.746 & - & 1.81 \\
\hline \multirow{5}{*}{ Mulch (M) } & WM & $48.09^{a}$ & $45.61^{\mathrm{a}}$ & $46.28^{a}$ \\
\hline & BM & $46.75^{b}$ & $46.21^{\mathrm{a}}$ & $45.00^{b}$ \\
\hline & $\mathbf{N M}$ & $43.46^{\mathrm{c}}$ & $38.42^{b}$ & $39.98^{c}$ \\
\hline & $p$-value & $0.00001^{* *}$ & $0.00001 * *$ & $0.0001^{* *}$ \\
\hline & LSD 0.05 & 1.12 & 1.27 & 0.99 \\
\hline \multirow{5}{*}{ Irrigation (I) } & FI & $48.35^{\mathrm{a}}$ & $45.81^{\mathrm{a}}$ & $46.07^{\mathrm{a}}$ \\
\hline & PRD70 & $45.73^{b}$ & $43.05^{b}$ & $43.53^{b}$ \\
\hline & PRD50 & $44.22^{b}$ & $41.38^{c}$ & $41.66^{\mathrm{c}}$ \\
\hline & $p$-value & $0.00001^{* *}$ & $0.00001^{* *}$ & $0.0005^{* *}$ \\
\hline & LSD 0.05 & 1.66 & 1.09 & 1.41 \\
\hline $\mathbf{S} \times \mathbf{M}$ & $p$-value & 0.0016 ** & $0.035 *$ & $0.023 *$ \\
\hline $\mathbf{S} \times \mathbf{I}$ & $p$-value & $0.806^{\mathrm{ns}}$ & $0.101^{n s}$ & $0.440^{\mathrm{ns}}$ \\
\hline $\mathbf{M} \times \mathbf{I}$ & $p$-value & $0.831^{\mathrm{ns}}$ & 0.0265 * & $0.265^{n s}$ \\
\hline $\mathbf{S} \times \mathbf{M} \times \mathbf{I}$ & $p$-value & $0.718^{\mathrm{ns}}$ & $0.122^{n s}$ & $0.063^{\mathrm{ns}}$ \\
\hline
\end{tabular}

ns: not statistically significant, ${ }^{* *}$ : significant at the $1 \%$ level $(p<0.01),{ }^{*}$ : significant at the $5 \%$ level $(p<0.05)$; different letters indicate significant difference between treatments; bold letters and words indicate treatments names.

Mulched treatments significantly affected $(p<0.001)$ chlorophyll index values (Table 3$)$. Our study showed that the SPAD value of mulch treatments was significantly higher than non-mulched treatments. The primary reason for the high SPAD value with mulch treatment could be that the film mulch changed the soil water content (Figure 5) and the heat environment in the root area of the squash, causing a change in the physical and chemical properties of the soil, which accelerated root system growth. Kante et al. [70] showed that a reduction in the chlorophyll content of plant leaves was directly associated with root growth. This result follows the same trend as the findings of Hugar et al. [71], Nasrullah et al. [72], and Iqbal et al. [73], who found that soil mulch enhances chlorophyll content compared with non-mulched treatments.

Drought stress reduced the chlorophyll index at all growth stages. PRD70 and PRD50 reduced the chlorophyll content. Under conditions of water stress, chlorophyll content declines as a result of damage to chloroplast membranes and structure and photo-oxidation of chlorophyll [74-76]. The reduction of leaf chlorophyll values due to a water deficit has been reported for squash [23], cabbage [58], cotton [73], and wheat [67] crops.

Chlorophyll index values were not significantly affected by the interactions between $\mathrm{S} \times \mathrm{M} \times \mathrm{I}$. However, the interaction between $\mathrm{S} \times \mathrm{M}$ was significant $(p<0.05)$ at all measured days. At 63 DAS, the interaction effect between mulch and irrigation treatments on SPAD value was significance. In FI treatments, BM increased SPAD value $6 \%$ and $23 \%$ compared with NM. In PRD70, the SPAD values under BM and WM were not different. BM and WM both increased SPAD values 17\% compared with NM. Under PRD50, WM increased SPAD values $3 \%$ and $24 \%$, respectively compared with BM and NM. Overall, FI and BM improved Pn, Tr and SPAD value.

\subsection{Fruit Quality}

Table 4 shows the statistical analysis of squash fruit quality, total soluble solids (TSS), total acidity $(\mathrm{TA})$, and vitamin $\mathrm{C}\left(\mathrm{V}_{\mathrm{C}}\right)$ under mulch and irrigation treatments for the WS and SS. The fruit qualities of the FI treatment were significantly different $(p<0.001)$ to 
those of the PRD treatments. Squash plants under the PRD50 treatments reduced TSS, TA, and $\mathrm{V}_{\mathrm{C}}$ by $17 \%, 25 \%$, and $19 \%$, respectively, compared with the FI treatment. The severe water stress treatment (PRD50) negatively affected the squash fruit quality. This finding could be explained by the water deficit causing a reduction in fruit water potential [25]. These results are in agreement with the findings of Al-Ghobari and Dewidar [24], Abd El-Mageed et al. [34], Kuslu et al. [77] and Zhang et al. [25], who found that water-stressed treatments reduced fruit qualities compared with non-stressed water. Fruit quality under PRD can be affected by many factors, including plant type, developmental stage, soil type, and environmental conditions [62].

Table 4. Analysis of variance of squash fruit quality, total soluble solids (TSS), total acidity (TA), and vitamin $\mathrm{C}\left(\mathrm{V}_{\mathrm{C}}\right)$ for winter and spring growing seasons.

\begin{tabular}{|c|c|c|c|c|}
\hline Treatments & & TSS (\%) & TA (\% Citric Acid) & $V_{C}(m g / 100 \mathrm{~g} F W)$ \\
\hline \multirow{4}{*}{ Season (S) } & WS & $4.98^{b}$ & 0.311 & 0.727 \\
\hline & SS & $5.52^{\mathrm{a}}$ & 0.334 & 0.746 \\
\hline & $p$-value & $0.036 *$ & $0.1785^{\mathrm{ns}}$ & $0.602^{n s}$ \\
\hline & LSD 0.05 & 0.149 & - & - \\
\hline \multirow{5}{*}{ Mulch (M) } & WM & $5.47^{b}$ & $0.340^{b}$ & $0.760^{b}$ \\
\hline & $\mathrm{BM}$ & $5.63^{a}$ & $0.342^{\mathrm{a}}$ & $0.775^{\mathrm{a}}$ \\
\hline & NM & $4.71^{\mathrm{c}}$ & $0.287^{c}$ & $0.675^{c}$ \\
\hline & $p$-value & $0.00001^{* *}$ & $0.0002 * *$ & $0.0018^{* *}$ \\
\hline & LSD 0.05 & 0.052 & 0.018 & 0.045 \\
\hline \multirow{5}{*}{ Irrigation (I) } & FI & $5.85^{\mathrm{a}}$ & $0.373^{a}$ & $0.813^{a}$ \\
\hline & PRD70 & $5.63^{b}$ & $0.313^{b}$ & $0.733^{b}$ \\
\hline & PRD50 & $4.86^{\mathrm{c}}$ & $0.281^{c}$ & $0.663^{c}$ \\
\hline & $p$-value & $0.0001^{* *}$ & $0.00001 * *$ & $0.00001^{* *}$ \\
\hline & LSD 0.05 & 0.048 & 0.017 & 0.043 \\
\hline $\mathbf{S} \times \mathbf{M}$ & $p$-value & $0.0003 * *$ & 0.0457 * & $0.036^{*}$ \\
\hline $\mathbf{S} \times \mathbf{I}$ & $p$-value & $0.00001^{* *}$ & $0.0047^{* *}$ & $0.182^{\mathrm{ns}}$ \\
\hline $\mathbf{M} \times \mathbf{I}$ & $p$-value & $0.357^{\mathrm{ns}}$ & $0.958^{\mathrm{ns}}$ & $0.908^{\mathrm{ns}}$ \\
\hline $\mathbf{S} \times \mathbf{M} \times \mathbf{I}$ & $p$-value & $0.635^{\mathrm{ns}}$ & $0.917^{\mathrm{ns}}$ & $0.906^{\mathrm{ns}}$ \\
\hline
\end{tabular}

ns: not statistically significant, ${ }^{* *}:$ significant at the $1 \%$ level $(p<0.01),{ }^{*}:$ significant at the $5 \%$ level $(p<0.05)$; different letters indicate significant difference between treatments; bold letters and words indicate treatments names.

Mulching significantly affected $(p<0.0001)$ all fruit quality attributes. Mulch treatments increased the TSS, TA, and $\mathrm{V}_{\mathrm{C}}$ by $16 \%, 16 \%$, and $13 \%$, respectively, compared with non-mulched treatments. This result is consistent with those of Lira-Saldivar et al. [36] and $\mathrm{Li}$ et al. [78], who found that soil mulching enhances fruit quality, compared with non-mulching. Abd El-Mageed et al. [34] indicated that mulch could reduce the influence of water stress on squash fruit quality, as mulch reduces soil evaporation, while preserving soil moisture content near the root zone.

Growing seasons did not significantly $(p>0.05)$ affect fruit quality, except for TSS. The interaction effect between $\mathrm{S} \times \mathrm{I}$ on TSS and TA was significant $(p<0.001)$. However, there was no significant $(p>0.05)$ difference in the value of $\mathrm{V}_{C}$. Squash fruit qualities were not significantly affected by the interactions of $\mathrm{S} \times \mathrm{M} \times \mathrm{I}$. In contrast, the effect of the interaction of $\mathrm{S} \times \mathrm{M}$ showed a significant difference $(p<0.05)$ between all fruit qualities.

\subsection{Yield and Irrigation Water Use Efficiency (IWUE)}

Statistical analysis of squash yield and IWUE are shown in Table 5. Squash yield was significantly $(p<0.05)$ affected by growing season. The squash yield obtained in the SS was higher (19\%) than that in the WS. The reduction of squash yield in the WS could be due to extreme lower temperatures and solar radiations during the WS than SS (Figure 1). Similar results were obtained for cucumber by Wan et al. [79] and for squash by Amer [37], who reported that the different yields, obtained in different growing seasons, were due to 
non-favorable weather conditions. Similarly, the higher yield recorded during the SS was due to an increase in physiological properties $\left(\mathrm{g}_{\mathrm{s}}, \mathrm{P}_{\mathrm{n}}\right.$, and $\left.\mathrm{T}_{\mathrm{r}}\right)$ and the chlorophyll index, compared with WS (Tables 2 and 3).

Table 5. Analysis of variance of squash fresh fruit yield and irrigation water use efficiency (IWUE) for winter (WS) and spring (SS) growing seasons.

\begin{tabular}{|c|c|c|c|}
\hline Treatments & & Fresh Fruit Yield $\left(\mathrm{Mg} \mathrm{ha}^{-1}\right)$ & IWUE $\left(\mathrm{kg} \mathrm{m}^{-3}\right)$ \\
\hline \multirow{4}{*}{ Season (S) } & WS & $72.12^{b}$ & $26.71^{a}$ \\
\hline & SS & $85.88^{\mathrm{a}}$ & $12.92^{b}$ \\
\hline & $p$-value & $0.0118 *$ & $0.0005^{* *}$ \\
\hline & LSD 0.05 & 6.49 & 1.35 \\
\hline \multirow{5}{*}{ Mulch (M) } & WM & $87.46^{\mathrm{a}}$ & $22.51^{\mathrm{a}}$ \\
\hline & $\mathbf{B M}$ & $85.30^{\mathrm{a}}$ & $21.74^{\mathrm{b}}$ \\
\hline & NM & $64.23^{c}$ & $15.20^{c}$ \\
\hline & $p$-value & $0.00001 * *$ & $0.0001 * *$ \\
\hline & LSD 0.05 & 3.41 & 0.45 \\
\hline \multirow{5}{*}{ Irrigation (I) } & FI & $80.62^{a}$ & $15.07^{\mathrm{c}}$ \\
\hline & PRD70 & $82.53^{\mathrm{a}}$ & $20.48^{b}$ \\
\hline & PRD50 & $73.85^{c}$ & $23.90^{\mathrm{a}}$ \\
\hline & $p$-value & $0.0001 * *$ & $0.0001^{* *}$ \\
\hline & LSD 0.05 & 2.51 & 0.52 \\
\hline $\mathbf{S} \times \mathbf{M}$ & $p$-value & $0.0001 * *$ & $0.0001 * *$ \\
\hline $\mathbf{S} \times \mathbf{I}$ & $p$-value & $0.0003^{* *}$ & $0.0001^{* *}$ \\
\hline $\mathbf{M} \times \mathbf{I}$ & $p$-value & $0.474^{\mathrm{ns}}$ & $0.0001^{* *}$ \\
\hline $\mathbf{S} \times \mathbf{M} \times \mathbf{I}$ & $p$-value & $0.773^{\text {ns }}$ & $0.0001^{* *}$ \\
\hline
\end{tabular}

The mulching treatments showed a significant difference $(p<0.0001)$ in squash yield compared with the non-mulched treatments (Table 5). Mulched treatments increased squash yield by $36 \%$ compared with non-mulched treatments. However, no statistical difference was observed between mulched treatments (BM and WM). The yield increase observed in the plastic mulch treatment could be attributed to its ability to reduce evaporation, fertilizer leaching, weed accumulation, and soil compaction and increase soil temperature, which enhances root growth [30,31]. These properties led to higher soil moisture and nutrient holding in the root zone, which eventually enhanced squash yield, compared with NM. Many studies have reported that mulch enhances crop yield in squash [34], cucumber [59], chili [80] and broccoli [35].

Squash yield was significantly $(p<0.001)$ affected by irrigation treatments. The highest squash yield was obtained under the PRD70 treatment $\left(82.53 \mathrm{Mg} \mathrm{ha}^{-1}\right)$. Although this yield was not significantly different from that of the FI treatment $\left(80.62 \mathrm{Mg} \mathrm{ha}^{-1}\right)$. This suggests that reducing the irrigation volume perfectly could improve fruit yield. The higher squash yield in the PRD70 treatment than the FI treatment could be partially explained by the PRD having parallel drip lines that irrigate the root zone of the plant interchangeably. This could reduce water losses due to deep percolation in sandy soil, resulting in nutrient availability near the root zone in plants under PRD treatments. Another possible reason for the PRD70 plot having a higher yield than the FI plot is that plastic mulch could prevent soil evaporation to some degree. Therefore, plots under the FI treatment might be over irrigated, and irrigation of $70 \%$ of crop water requirement supplies sufficient water for crop growth without stress [81]. Hakim et al. [17] indicate that plants receiving FI could encounter higher soil moisture in the root zone, which reduces root activity, delaying maturity, and lowering yield compared with plants under PRD treatments. This result is consistent with the findings of Qin et al. [20] and Hooshmand et al. [19], who found that the yield of the FI treatment was lower than the deficit treatments, but not significantly different. Howerver, 
the squash yield obtained in this study was more than three times higher than the squash yield obtained by Al-Omran et al. [82] under the same environmental conditions. This finding could be attributed to the higher plant density and good fertilization program used in this experiment, resulting in a higher squash yield compared with the mentioned study.

The interaction effects between $\mathrm{S} \times \mathrm{M} \times \mathrm{I}$ were not statistically significant $(p>0.05)$ for squash yield, while there were strong significant $(p<0.001)$ interactions between $\mathrm{S} \times \mathrm{M}$ and $\mathrm{S} \times \mathrm{I}$ (Table 5). It is worth mension that sowing squash in the SS under non-mulched treatment was almost doubled the squash yield compared to sowing in the WS. The variation of squash yield under mulched treatments in the SS and WS was not considerable. This shows that WM and BM were effective during both growing seasons (Figure 6). The highest squash yield was recorded under SS-BM-PRD70 treatment $\left(95.84 \mathrm{Mg} \mathrm{ha}^{-1}\right)$, while the lowest yield (46.06 $\mathrm{Mg} \mathrm{ha}^{-1}$ ) was obtained under WS-NM-PRD50. In the WS, the highest squash yield obtained was $87.9 \mathrm{Mg} \mathrm{ha}^{-1}$ in WM PRD70, while in the SS, the lowest squash yield obtained was $75.33 \mathrm{Mg} \mathrm{ha}^{-1}$ in NM PRD50. The Squash yield obtained under SS-NM-FI and WS-NM-FI were 77.4, and $53.1 \mathrm{Mg} \mathrm{ha}^{-1}$, respectively, while in SS-WMPRD50 and WS-WM-PRD50 were 85.29 , and $79.34 \mathrm{Mg} \mathrm{ha}^{-1}$, respectively (Figure 6). This shows that using the PRD strategy and soil mulching technique reduces $50 \%$ of applied water, while increasing squash yield in both growing seasons. These results suggest that in arid and semi-arid regions where there are water scarcity problems, soil mulch with PRD50 could be used as a water-saving strategy to maintain the squash yield.

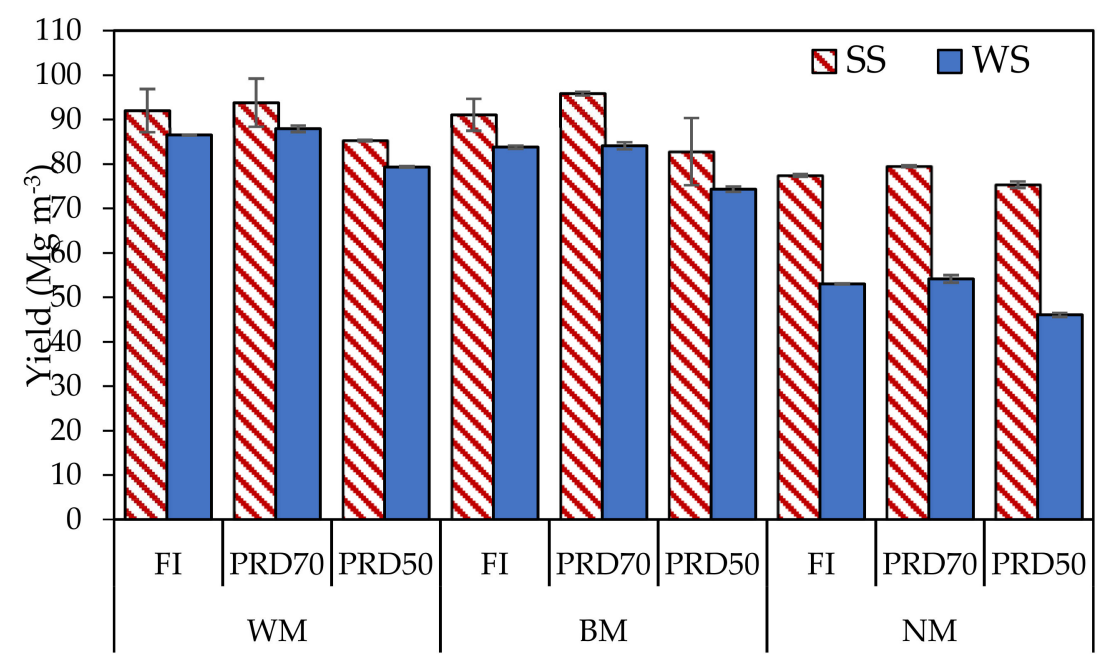

Figure 6. Squash yield under irrigation and mulch treatments during the winter and spring seasons.

Data presented in Table 5 and Figure 7 show that the effect of S, M, and I on IWUE was significant $(p<0.001)$. The IWUE in the WS was two times higher than in the SS. This result could be due to the water applied to squash in the SS, which was higher than that applied in the WS. This finding is in line with those recorded by Rouphael and Colla [83], Abd El-Mageed and Semida [9], Abd El-Mageed et al. [34] and Silva et al. [38], who worked on squash and observed that the IWUE was affected by environmental factors under different growing seasons. 


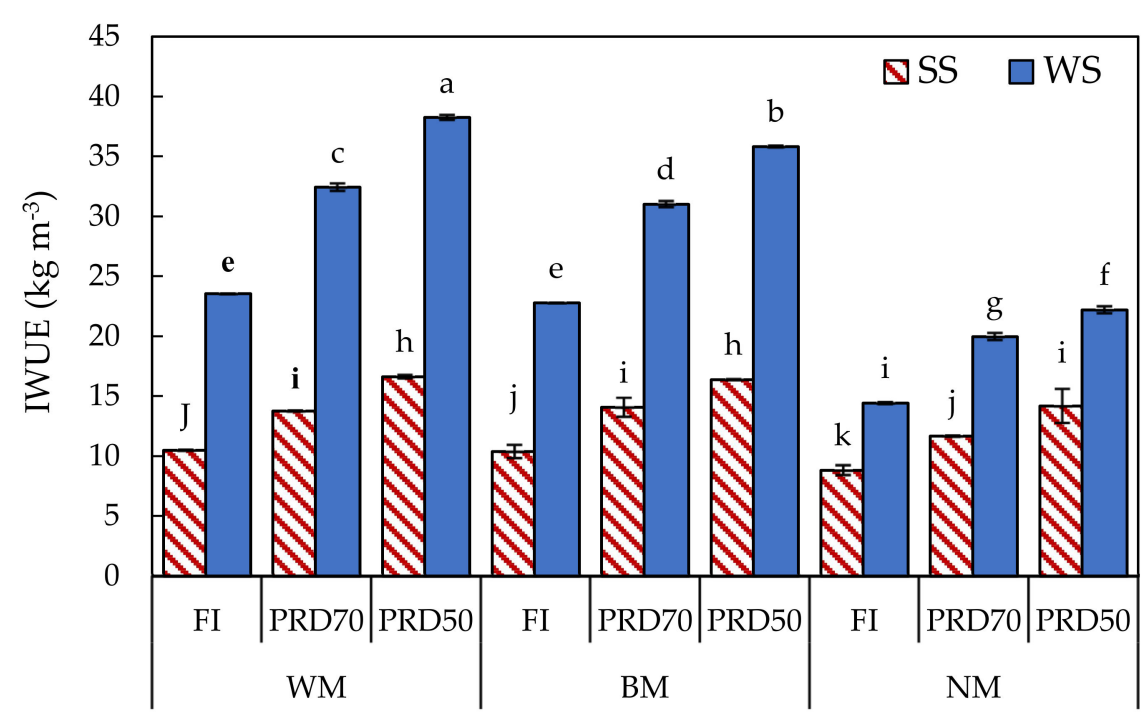

Figure 7. Squash irrigation water use efficiency (IWUE) during winter (WS) and spring (SS) under mulch treatments (black mulch-BM, transparent mulch-WM and non-mulch- NM) and irrigation treatments (full irrigation-FI, partial root drying with 50\% of evapotranspiration- PRD50, partial root drying with $70 \%$ of evapotranspiration-PRD70); the data is the mean value \pm standard error; different letters indicate significant difference between treatments.

In terms of the mulching treatments, WM increased the IWUE by $48 \%$ compared with the NM treatments (Table 5). Soil mulching decreased evaporation and increased the soil moisture content near the root zone, which positively affected the squash yield, and finally, it contributed to higher IWUE. This result is consistent with the findings of Zhang et al. [81], Chen et al. [84], and Yang et al. [61], who found that mulching treatments had higher IWUE than the control treatment (NM).

In terms of irrigation quantities, the highest IWUE was observed under PRD50 treatments $\left(23.90 \mathrm{~kg} \mathrm{~m}^{-3}\right)$. The corresponding value for the FI treatments was $15.07 \mathrm{~kg} \mathrm{~m}^{-3}$ (Table 5). PRD50 and PR70 increased the IWUE by 59\%, and 36\%, respectively, compared with the FI treatment. These results are in agreement with Amer [37], Abd ElMageed et al. [34], and Zhang et al. [81], who found that water-stressed treatments increase the IWUE, compared with FI.

Data presented in Table 5 show that the interaction effects of the $\mathrm{S} \times \mathrm{M}, \mathrm{S} \times \mathrm{I}, \mathrm{M} \times \mathrm{I}$, and $\mathrm{S} \times \mathrm{M} \times \mathrm{I}$ on IWUE were significant $(p<0.001)$. The highest IWUE $\left(38.24 \mathrm{~kg} \mathrm{~m}^{-3}\right)$ was recorded under WS-WM-PRD50, while the lowest value was $8.82 \mathrm{~kg} \mathrm{~m}^{-3}$ under SS-NM-FI (Figure 7). The IWUE in the WS were doubled compared with SS for mulch treatments under same irrigation treatments. It can be seen from Figure 7 that PRD50 obtained higher IWUE in mulch and non-mulched treatments, compared with PRD70 and FI. Overall, Sowing squash in WS, FI-NM obtained squash yield of $53.1 \mathrm{Mg} \mathrm{ha}^{-1}$ with IWUE $14.42 \mathrm{~kg} \mathrm{~m}^{-3}$, while PRD50-WM obtained $79.34 \mathrm{Mg} \mathrm{ha}^{-1}$ with IWUE $38.24 \mathrm{~kg} \mathrm{~m}^{-3}$. This result led to conculde that sowing squash in WS using PRD50-WM saves $50 \%$ of applied water while increases squash yield by $49 \%$, compared with FI-NM.

\section{Conclusions}

The effect of growing season DI integrated with PRD, and soil mulching on the yield and IWUE of squash plants, was studied. The results indicated that plant density postively affected squash yield in both growing seasons for all treatments. The spring growing season positively affected squash yield. In contrast, the SS negatively affected the IWUE, compared with the WS. Moreover, soil mulching enhanced the physiological properties of the squash plants $\left(\mathrm{g}_{\mathrm{s}}, \mathrm{P}_{\mathrm{n}}\right.$, and $\left.\mathrm{T}_{\mathrm{r}}\right)$, fruit quality (TSS, TA, and $\left.\mathrm{Vc}\right)$, increasing the squash yield, and IWUE, compared with non-mulched treatments. $g_{s}, P_{n}$ and $T_{r}$ were significantly affected by growing season for all measured days. Furthermore, PRD70 and PRD50 reduced the 
chlorophyll index at all growth stages. Mulch treatments increased the TSS, TA, and $\mathrm{V}_{\mathrm{C}}$, compared with non-mulched treatments. However, growing seasons did not significantly affect fruit quality. In addition, PRD strategy improved both squash yield and IWUE in both growing seasons. This emphasizes that sowing squash plants in the winter season, using PRD50 and plastic mulch as water-saving strategies, could increase the yield and IWUE in arid and semi-arid regions.

Author Contributions: Conceptualization, H.M.A.-G., T.K.Z.E.-A. and A.A.E.-S.; methodology, A.A.E.-S., A.H.F. and M.S.A.; software, A.A.E.-S., A.H.F. and M.S.A.; validation, H.M.A.-G., T.K.Z.E.A. and A.A.E.-S.; formal analysis, A.H.F. and M.S.A.; investigation, A.H.F. and M.S.A.; resources, H.M.A.-G. and T.K.Z.E.-A.; data curation, A.A.E.-S., A.H.F. and M.S.A.; writing-original draft preparation, A.A.E.-S. and A.H.F.; writing—review and editing, H.M.A.-G., T.K.Z.E.-A., A.A.E.-S. and A.H.F.; visualization, T.K.Z.E.-A. and A.A.E.-S.; supervision, H.M.A.-G. and T.K.Z.E.-A.; project administration, H.M.A.-G. and T.K.Z.E.-A.; funding acquisition, H.M.A.-G., T.K.Z.E.-A. and M.S.A. All authors have read and agreed to the published version of the manuscript.

Funding: This research was funded by the Deanship of Scientific Research at King Saud University, through research group No. RG-1441-321.

Institutional Review Board Statement: Not applicable.

Informed Consent Statement: Not applicable.

Data Availability Statement: The data presented in this study are available on request from the corresponding author.

Acknowledgments: The authors extend their appreciation to the Deanship of Scientific Research at King Saud University for funding this work through research group No. RG-1441-321.

Conflicts of Interest: The authors declare no conflict of interest. The funders had no role in the design of the study; in the collection, analyses, or interpretation of data; in the writing of the manuscript, or in the decision to publish the results.

\section{References}

1. Wang, X.; Huo, Z.; Guan, H.; Guo, P.; Qu, Z. Drip irrigation enhances shallow groundwater contribution to crop water consumption in an arid area. Hydrol. Process. 2018, 32, 747-758. [CrossRef]

2. Biswas, S.K.; Akanda, A.R.; Rahman, M.S.; Hossain, M.A. Effect of drip irrigation and mulching on yield, water-use efficiency and economics of tomato. Plant Soil Environ. 2015, 61, 97-102. [CrossRef]

3. Woodrow, J.E.; Seiber, J.N.; Lenoir, J.S.; Krieger, R.I. Determination of methyl isothiocyanate in air downwind of fields treated with metam-sodium by subsurface drip irrigation. J. Agric. Food Chem. 2008, 56, 7373-7378. [CrossRef]

4. Ayars, J.E.; Fulton, A.; Taylor, B. Subsurface drip irrigation in California-Here to stay? Agric. Water Manag. 2015, 157, $39-47$. [CrossRef]

5. Hashem, M.S.; Zin El-Abedin, T.; Al-Ghobari, H.M. Assessing effects of deficit irrigation techniques on water productivity of tomato for subsurface drip irrigation system. Int. J. Agric. Biol. Eng. 2018, 11, 156-167. [CrossRef]

6. Abdalhi, M.A.M.; Jia, Z. Crop yield and water saving potential for AquaCrop model under full and deficit irrigation managements. Ital. J. Agron. 2018, 13, 267-278. [CrossRef]

7. Khapte, P.S.; Kumar, P.; Burman, U.; Kumar, P. Deficit irrigation in tomato: Agronomical and physio-biochemical implications. Sci. Hortic. 2019, 248, 256-264. [CrossRef]

8. Puértolas, J.; Albacete, A.; Dodd, I.C. Irrigation frequency transiently alters whole plant gas exchange, water and hormone status, but irrigation volume determines cumulative growth in two herbaceous crops. Environ. Exp. Bot. 2020, 176, 104101. [CrossRef]

9. Abd El-Mageed, T.A.; Semida, W.M. Effect of deficit irrigation and growing seasons on plant water status, fruit yield and water use efficiency of squash under saline soil. Sci. Hortic. 2015, 186, 89-100. [CrossRef]

10. Jensen, M.E. Design and Operation of Farm Irrigation Systems; ASAE: Detroit, MI, USA, 1983; pp. 108-118.

11. Bacon, M.A. Water use efficiency in plant biology. In Water Use Efficiency in Plant Biology; Bacon, M.A., Ed.; CRC Press: Boca Raton, FL, USA, 2004; pp. 1-26.

12. Velasco-Muñoz, J.F.; Aznar-Sánchez, J.A.; Belmonte-Ureña, L.J.; López-Serrano, M.J. Advances in Water Use Efficiency in Agriculture: A Bibliometric Analysis. Water 2018, 10, 377. [CrossRef]

13. Kang, S.; Zhang, J. Controlled alternate partial root-zone irrigation: Its physiological consequences and impact on water use efficiency. J. Exp. Bot. 2004, 55, 2437-2446. [CrossRef] 
14. Jensen, C.R.; Battilani, A.; Plauborg, F.; Psarras, G.; Chartzoulakis, K.; Janowiak, F.; Stikic, R.; Jovanovic, Z.; Li, G.; Qi, X.; et al. Deficit irrigation based on drought tolerance and root signalling in potatoes and tomatoes. Agric. Water Manag. 2010, $98,403-413$. [CrossRef]

15. Jovanovic, Z.; Stikic, R. Partial root-zone drying technique: From water saving to the improvement of a fruit quality. Front. Sustain. Food Syst. 2018, 1, 1-9. [CrossRef]

16. Barideh, R.; Besharat, S.; Morteza, M.; Rezaverdinejad, V. Effects of partial root-zone irrigation on the water use efficiency and root water and nitrate uptake of corn. Water 2018, 10, 526. [CrossRef]

17. Hakim, A.; Qinyan, Z.; Khatoon, M.; Gullo, S. Impact of partial root-zone drying on growth, yield and quality of tomatoes produced in green house condition. Adv. Hortic. Sci. 2019, 33, 133-138. [CrossRef]

18. Mattar, M.A.; Zin El-Abedin, T.K.; Alazba, A.A.; Al-Ghobari, H.M. Soil water status and growth of tomato with partial root-zone drying and deficit drip irrigation techniques. Irrig. Sci. 2020, 38, 163-176. [CrossRef]

19. Hooshmand, M.; Albaji, M.; Boroomand nasab, S.; Alam zadeh Ansari, N. The effect of deficit irrigation on yield and yield components of greenhouse tomato (Solanum lycopersicum)in hydroponic culture in Ahvaz region, Iran. Sci. Hortic. 2019, 254, 84-90. [CrossRef]

20. Qin, J.; Ramírez, D.A.; Xie, K.; Li, W.; Yactayo, W.; Jin, L.; Quiroz, R. Is Partial root-zone drying more appropriate than drip irrigation to save water in China? A preliminary comparative analysis for potato cultivation. Potato Res. 2018, 61, 391-406. [CrossRef]

21. Jovanovic, Z.; Stikic, R.; Vucelic-Radovic, B.; Paukovic, M.; Brocic, Z.; Matovic, G.; Rovcanin, S.; Mojevic, M. Partial root-zone drying increases WUE, $\mathrm{N}$ and antioxidant content in field potatoes. Eur. J. Agron. 2010, 33, 124-131. [CrossRef]

22. Xie, K.; Wang, X.X.; Zhang, R.; Gong, X.; Zhang, S.; Mares, V.; Gavilán, C.; Posadas, A.; Quiroz, R. Partial root-zone drying irrigation and water utilization efficiency by the potato crop in semi-arid regions in China. Sci. Hortic. 2012, 134, 20-25. [CrossRef]

23. Ors, S.; Ekinci, M.; Yildirim, E.; Sahin, U. Changes in gas exchange capacity and selected physiological properties of squash seedlings (Cucurbita pepo L.) under well-watered and drought stress conditions. Arch. Agron. Soil Sci. 2016, 62, 1700-1710. [CrossRef]

24. Al-Ghobari, H.M.; Dewidar, A.Z. Integrating deficit irrigation into surface and subsurface drip irrigation as a strategy to save water in arid regions. Agric. Water Manag. 2018, 209, 55-61. [CrossRef]

25. Zhang, K.; Dai, Z.; Wang, W.; Dou, Z.; Wei, L.; Mao, W.; Chen, Y.; Zhao, Y.; Li, T.; Zeng, B.; et al. Effects of partial root drying on strawberry fruit. Eur. J. Hortic. Sci. 2019, 84,39-47. [CrossRef]

26. Guang-Cheng, S.; Rui-Qi, G.; Na, L.; Shuang-En, Y.; Weng-Gang, X. Photosynthetic, chlorophyll fluorescence and growth changes in hot pepper under deficit irrigation and partial root zone drying. Afr. J. Agric. Res. 2011, 6, 4671-4679. [CrossRef]

27. Chakraborty, D.; Nagarajan, S.; Aggarwal, P.; Gupta, V.K.; Tomar, R.K.; Garg, R.N.; Sahoo, R.N.; Sarkar, A.; Chopra, U.K.; Sarma, K.S.S.; et al. Effect of mulching on soil and plant water status, and the growth and yield of wheat (Triticum aestivum L.) in a semi-arid environment. Agric. Water Manag. 2008, 95, 1323-1334. [CrossRef]

28. Sharma, R.; Bhardwaj, S. Effect of mulching on soil and water conservation: A review. Agric. Rev. 2017, 38, 311-315. [CrossRef]

29. Zhao, H.; Wang, R.Y.; Ma, B.L.; Xiong, Y.C.; Qiang, S.C.; Wang, C.L.; Liu, C.A.; Li, F.M. Ridge-furrow with full plastic film mulching improves water use efficiency and tuber yields of potato in a semiarid rainfed ecosystem. Field Crops Res. 2014, 161, 137-148. [CrossRef]

30. Mutetwa, M.; Mtaita, T. Effects of mulching and fertilizer sources on growth and yield of onion. J. Glob. Innov. Agric. Soc. Sci. 2014, 2, 102-106. [CrossRef]

31. Kader, M.A.; Senge, M.; Mojid, M.A.; Ito, K. Recent advances in mulching materials and methods for modifying soil environment. Soil Tillage Res. 2017, 168, 155-166. [CrossRef]

32. Yaghi, T.; Arslan, A.; Naoum, F. Cucumber (Cucumis sativus, L.) water use efficiency (WUE) under plastic mulch and drip irrigation. Agric. Water Manag. 2013, 128, 149-157. [CrossRef]

33. Kumari, P.; Ojha, R.K.; Job, M. Effect of plastic mulches on soil temperature and tomatoyield inside and outside the polyhouse. Agric. Sci. Digest 2016, 36, 333-336. [CrossRef]

34. Abd El-Mageed, T.A.; Semida, W.M.; Abd El-wahed, M.H. Effect of mulching on plant water status, soil salinity and yield of squash under summer-fall deficit irrigation in salt affected soil. Agric. Water Manag. 2016, 173, 1-12. [CrossRef]

35. Verma, V.K.; Jha, A.K.; Verma, B.C.; Nonglait, D.; Chaudhuri, P. Effect of Mulching materials on soil health, yield and quality attributes of broccoli grown under the mid-hill conditions. Proc. Natl. Acad. Sci. India Sect. B Biol. Sci. 2018, 88, 1589-1596. [CrossRef]

36. Lira-Saldivar, R.H.; Méndez-Argüello, B.; Felipe-Victoriano, M.; Vera-Reyes, I.; Cardenas-Flores, A.; Méndez-Argüello, B.; Felipe-Victoriano, M.; Vera-Reyes, I.; Cardenas-Flores, A.; Méndez-Argüello, B.; et al. Gas exchange, yield and fruit quality of Cucurbita pepo cultivated with zeolite and plastic mulch. Agrochimica 2017, 61, 123-139. [CrossRef]

37. Amer, K.H. Effect of irrigation method and quantity on squash yield and quality. Agric. Water Manag. 2011, 98, 1197-1206. [CrossRef]

38. Silva, G.H.; Cunha, F.F.; Morais, C.V.; Freitas, A.R.J.; Silva, D.J.H.; Souza, C.M.D. Mulching materials and wetted soil percentages on zucchini cultivation. Ciênc. Agrotecnol. 2020, 44, e006720. [CrossRef]

39. Allen, R.G.; Pereira, L.S.; Raes, D.; Smith, M. Crop Evapotranspiration-Guidelines for Computing Crop Water Requirements; FAO Irrigation and Drainage Paper 56; FAO: Rome, Italy, 1998. 
40. Buss, P. The use of capacitance based measurement of real time soil water profile dynamics for irrigation scheduling. In Proceedings of the National Conference Irrigation Association, Australia and National Committee Irrigation Drainage, Launceston, TAS, Australia, 17-19 May 1993.

41. Vera, J.; Mounzer, O.; Ruiz-Sánchez, M.C.; Abrisqueta, I.; Tapia, L.M.; Abrisqueta, J.M. Soil water balance experiments utilizing capacitance and neutron probe measurements in irrigation scheduling. In Transactions of the Second International Symposium on Soil Water Measurement Using Capacitance Impedance and Time Domain Transmission (TDT); Paltineanu, I.C., Ed.; Paltin International Incorporated: Beltsville, MD, USA, 2007; p. 180.

42. Li, Y.; Song, H.; Zhou, L.; Xu, Z.; Zhou, G. Tracking chlorophyll fluorescence as an indicator of drought and rewatering across the entire leaf lifespan in a maize field. Agric. Water Manag. 2019, 211, 190-201. [CrossRef]

43. Helrich, K. Official Methods of Analysis of the Association of Official Analytical Chemists; Association of Official Analytical Chemists: Arlington, VA, USA, 1990.

44. Caruso, G.; Conti, S.; Villari, G.; Borrelli, C.; Melchionna, G.; Minutolo, M.; Russo, G.; Amalfitano, C. Effects of transplanting time and plant density on yield, quality and antioxidant content of onion (Allium cepa L.) in southern Italy. Sci. Hortic. 2014, 166, 111-120. [CrossRef]

45. Patanè, C.; Tringali, S.; Sortino, O. Effects of deficit irrigation on biomass, yield, water productivity and fruit quality of processing tomato under semi-arid Mediterranean climate conditions. Sci. Hortic. 2011, 129, 590-596. [CrossRef]

46. CoStat. CoStat Version 6.451-Statistics Software; CoHort Software: Monterey, CA, USA, 2018.

47. Rashid, M.A.; Zhang, X.; Andersen, M.N.; Olesen, J.E. Can mulching of maize straw complement deficit irrigation to improve water use efficiency and productivity of winter wheat in North China plain? Agric. Water Manag. 2019, 213, 1-11. [CrossRef]

48. Wong, S.C.; Cowan, I.R.; Farquhar, G.D. Stomatal conductance correlates with photosynthetic capacity. Nature 1979, 282, 424-426. [CrossRef]

49. Tuzet, A.; Perrier, A.; Leuning, R. A coupled model of stomatal conductance, photosynthesis and transpiration. Plant Cell Environ. 2003, 26, 1097-1116. [CrossRef]

50. Liu, F.; Jensen, C.R.; Andersen, M.N. Hydraulic and chemical signals in the control of leaf expansion and stomatal conductance in soybean exposed to drought stress. Funct. Plant Biol. 2003, 30, 65-73. [CrossRef] [PubMed]

51. Parkash, V.; Singh, S. A Review on potential plant-based water stress indicators for vegetable crops. Sustainability 2020, $12,3945$. [CrossRef]

52. Raghavendra, A.S.; Gonugunta, V.K.; Christmann, A.; Grill, E. ABA Perception and Signalling. Trends Plant Sci. 2010, 15, 395-401. [CrossRef]

53. Sperry, J.S.; Alder, N.N.; Eastlack, S.E. The effect of reduced hydraulic conductance on stomatal conductance and xylem cavitation. J. Exp. Bot. 1993, 44, 1075-1082. [CrossRef]

54. Farooq, M.; Wahid, A.; Kobayashi, N.; Fujita, D.; Basra, S.M.A. Plant Drought Stress: Effects, Mechanisms and Management. In Sustainable Agriculture; Lichtfouse, E., Navarrete, M., Debaeke, P., Véronique, S., Alberola, C., Eds.; Springer: Dordrecht, The Netherlands, 2009; pp. 153-188.

55. Shirke, P.A. Leaf photosynthesis, dark respiration and fluorescence as influenced by leaf age in an evergreen tree. Prosop. Juliflor. 2001, 39, 305-311. [CrossRef]

56. Du, T.; Kang, S.; Zhang, J.; Li, F.; Hu, X. Yield and physiological responses of cotton to partial root-zone irrigation in the oasis field of northwest China. Agric. Water Manag. 2006, 84, 41-52. [CrossRef]

57. Romero, P.; Dodd, I.C.; Martinez-Cutillas, A. Contrasting physiological effects of partial root zone drying in field-grown grapevine (Vitis vinifera L. cv. Monastrell) according to total soil water availability. J. Exp. Bot. 2012, 63, 4071-4083. [CrossRef]

58. Sahin, U.; Ekinci, M.; Ors, S.; Turan, M.; Yildiz, S.; Yildirim, E. Effects of individual and combined effects of salinity and drought on physiological, nutritional and biochemical properties of cabbage (Brassica oleracea var. capitata). Sci. Hortic. 2018, 240, 196-204. [CrossRef]

59. Ibarra-Jiménez, L.; Zermeño-González, A.; Munguía-López, J.; Rosario Quezada-Martín, M.A.; De La Rosa-Ibarra, M. Photosynthesis, soil temperature and yield of cucumber as affected by colored plastic mulch. Acta Agric. Scandinav. Sect. B Plant Soil Sci. 2008, 58, 372-378. [CrossRef]

60. Wang, F.; Wang, Z.; Zhang, J.; Li, W. Combined effect of different amounts of irrigation and mulch films on physiological indexes and yield of drip-irrigated maize (Zea mays L.). Water 2019, 11, 472. [CrossRef]

61. Yang, Y.; Ding, J.; Zhang, Y.; Wu, J.; Zhang, J.; Pan, X.; Gao, C.; Wang, Y.; He, F. Effects of tillage and mulching measures on soil moisture and temperature, photosynthetic characteristics and yield of winter wheat. Agric. Water Manag. 2018, 201, 299-308. [CrossRef]

62. Zhang, X.; Yang, L.; Xue, X.; Kamran, M.; Ahmad, I.; Dong, Z.; Liu, T.; Jia, Z.; Zhang, P.; Han, Q. Plastic film mulching stimulates soil wet-dry alternation and stomatal behavior to improve maize yield and resource use efficiency in a semi-arid region. Field Crops Res. 2019, 233, 101-113. [CrossRef]

63. Li, Q.; Shen, J.; Zhao, D. Effect of irrigation frequency on yield and leaf water use efficiency of winter wheat. Trans. Chin. Soc. Agric. Eng. 2011, 27, 33-36.

64. Urban, J.; Ingwers, M.; McGuire, M.A.; Teskey, R.O. Stomatal conductance increases with rising temperature. Plant Signal. Behav. 2017, 12, e1356534. [CrossRef] [PubMed] 
65. Jones, H.G.; Serraj, R.; Loveys, B.R.; Xiong, L.; Wheaton, A.; Price, A.H. Thermal infrared imaging of crop canopies for the remote diagnosis and quantification of plant responses to water stress in the field. Funct. Plant Biol. 2009, 36, 978-989. [CrossRef]

66. Scherrer, D.; Bader, M.K.-F.; Körner, C. Drought-sensitivity ranking of deciduous tree species based on thermal imaging of forest canopies. Agric. Forest Meteorol. 2011, 151, 1632-1640. [CrossRef]

67. Talebi, R. Evaluation of chlorophyll content and canopy temperature as indicators for drought tolerance in durum wheat (Triticum durum Desf.). Aust. J. Basic Appl. Sci. 2011, 5, 1457-1462.

68. Li, R.H.; Guo, P.G.; Michael, B.; Stefania, G.; Salvatore, C. Evaluation of Chlorophyll Content and Fluorescence Parameters as Indicators of Drought Tolerance in Barley. Agric. Sci. China 2006, 5, 751-757. [CrossRef]

69. Peiguo, G.; Mingqi, L. Studies on photosynthetic characteristics in rice hybrid progenies and their parents I. Chlorophyll content, chlorophyll-Protein complex and chlorophyll fluorescence kinetics. J. Trop. Subtrop. Bot. 1996, 4, 60-65.

70. Kante, M.; Revilla, P.; De La Fuente, M.; Caicedo, M.; Ordás, B. Stay-green QTLs in temperate elite maize. Euphytica 2016, 207, 463-473. [CrossRef]

71. Hugar, A.Y.; Halemani, H.L.; Aladakatti, Y.R.; Nandagavi, R.A.; Hallikeri, S.S. Studies on the effect of polyethylene mulching on rainfed cotton genotypes: II. Influence on status of soil moisture, microbial population in soil and uptake of nutrients. Karnataka J. Agric. Sci. 2009, 22, 284-288.

72. Nasrullah, M.; Khan, M.B.; Ahmad, R.; Ahmad, S.; Hanif, M.; Nazeer, W. Sustainable cotton production and water economy through different planting methods and mulching techniques. Pak. J. Bot. 2011, 43, 1971-1983.

73. Iqbal, R.; Raza, M.A.S.; Saleem, M.F.; Khan, I.H.; Ahmad, S.; Zaheer, M.S.; Aslam, M.U.; Haider, I. Physiological and biochemical appraisal for mulching and partial rhizosphere drying of cotton. J. Arid Land 2019, 11, 785-794. [CrossRef]

74. Kingston-Smith, A.H.; Foyer, C.H. Bundle sheath proteins are more sensitive to oxidative damage than those of the mesophyll in maize leaves exposed to paraquat or low temperatures. J. Exp. Bot. 2000, 51, 123-130. [CrossRef] [PubMed]

75. Amirjani, M.R.; Mahdiyeh, M. Antioxidative and biochemical responses of wheat to drought stress. J. Agric. Biol. Sci. 2013, 8, 291-301.

76. Kabiri, R.; Nasibi, F.; Farahbakhsh, H. Effect of exogenous salicylic acid on some physiological parameters and alleviation of drought stress in Nigella sativa plant under hyroponic culture. Plant Protect. Sci. 2014, 50, 43-51. [CrossRef]

77. Kuslu, Y.; Sahin, U.; Kiziloglu, F.M.; Memis, S. Fruit yield and quality, and irrigation water use efficiency of summer squash drip-irrigated with different irrigation quantities in a semi-arid agricultural area. J. Integrat. Agric. 2014, 13, 2518-2526. [CrossRef]

78. Li, H.; Yang, X.; Chen, H.; Cui, Q.; Yuan, G.; Han, X.; Wei, C.; Zhang, Y.; Ma, J.; Zhang, X. Water requirement characteristics and the optimal irrigation schedule for the growth, yield, and fruit quality of watermelon under plastic film mulching. Sci. Hortic. 2018, 241, 74-82. [CrossRef]

79. Wan, S.; Kang, Y.; Wang, D.; Liu, S.P. Effect of saline water on cucumber (Cucumis sativus L.) yield and water use under drip irrigation in North China. Agric. Water Manag. 2010, 98, 105-113. [CrossRef]

80. Khan, M.N.; Ayub, G.; Ilyas, M.; Haq, F.U.; Ali, J.; Alam, A. Effect of different mulching materials on weeds and yield of Chili cultivars. Pure Appl. Biol. 2016, 5, 1160-1170. [CrossRef]

81. Zhang, H.; Xiong, Y.; Huang, G.; Xu, X.; Huang, Q. Effects of water stress on processing tomatoes yield, quality and water use efficiency with plastic mulched drip irrigation in sandy soil of the Hetao Irrigation District. Agric. Water Manag. 2017, 179, 205-214. [CrossRef]

82. Al-Omran, A.M.; Sheta, A.S.; Falatah, A.M.; Al-Harbi, A.R. Effect of drip irrigation on squash (Cucurbita pepo) yield and water-use efficiency in sandy calcareous soils amended with clay deposits. Agric. Water Manag. 2005, 73, 43-55. [CrossRef]

83. Rouphael, Y.; Colla, G. Growth, yield, fruit quality and nutrient uptake of hydroponically cultivated zucchini squash as affected by irrigation systems and growing seasons. Sci. Hortic. 2005, 105, 177-195. [CrossRef]

84. Chen, Z.; Sun, S.; Zhu, Z.; Jiang, H.; Zhang, X. Assessing the effects of plant density and plastic film mulch on maize evaporation and transpiration using dual crop coefficient approach. Agric. Water Manag. 2019, 225, 105765. [CrossRef] 